\title{
BEACHED BIRD SURVEYS ON SABLE ISLAND, NOVA SCOTIA, 1993 TO 2009, SHOW A DECLINE IN THE INCIDENCE OF OILING
}

\author{
ZOE LUCAS ${ }^{1}$, ANDREW HORN², and \\ BILL FREEDMAN ${ }^{2}$ \\ IP.O. Box 64, Halifax CRO, Nova Scotia B3J 2L4, Canada \\ zoelucas@greenhorsesociety.com \\ ${ }^{2}$ Biology Department, Dalhousie University, \\ Halifax, Nova Scotia B4H 4J1, Canada \\ aghorn@dal.ca\&bill.freedman@dal.ca
}

Sable Island, located about $160 \mathrm{~km}$ southeast of the landmass of Nova Scotia, Canada, is far offshore and provides a platform for beach surveys to monitor oil pollution in Scotian Shelf waters. Sporadic beach surveys conducted there during the 1970s and 1980s indicated that oiled birds and beached tar were common occurrences. During a survey program from January 1993 to December 2009, more than 10,800 bird corpses were found in 171 surveys covering a total of $>13,500 \mathrm{~km}$ of shoreline. Sixtyfour species were recorded, of which 52 were seabirds and waterfowl. The numbers of beached birds and species composition exhibited large fluctuations, which reflected both the seasonal distribution of species and the effects of weather and beach conditions. The oiling rate of corpses for all seabirds and waterfowl combined was $28.6 \%$, and ranged from a high of $69.9 \%$ in 1996 to a low of $1.4 \%$ in 2009 . Alcids had the highest rates of oiling (averaging 54.3\%), while lower rates were observed for shearwaters (1.9\%) and Larus gulls (2.4\%). The results of the 1993-2009 surveys, as well as those of earlier studies in the 1970s and 1980s, indicate a declining trend in the oiling rate of beached birds on Sable Island.

Keywords: oil pollution, marine pollution, seabird oiling rate, beached bird survey, Sable Island

\section{INTRODUCTION}

Millions of seabirds of more than 20 species breed along the coasts and islands of Atlantic Canada (Brown et al. 1975, Lock et al. 1994). In offshore waters of Nova Scotia, the seabirds are predominantly non-breeding individuals of species that breed in boreal and arctic waters of the North Atlantic, and they are especially abundant in the winter (Lock et al. 1994). In addition, a number of pelagic species that breed in the Southern Hemisphere migrate to the northwest Atlantic 
during the northern summer (Lock et al. 1994). Consequently, there is a large and varied seabird fauna in waters of the Scotian Shelf and its slope at all times of the year. These birds are highly vulnerable to oil pollution from shipping and ship-based activities in their marine environment.

The continental shelf averages about $200 \mathrm{~km}$ wide off Nova Scotia, and Sable Island is located near its outer edge (Sable Island Station: $\left.43.9330^{\circ} \mathrm{N},-60.0055^{\circ} \mathrm{W}\right)$. The island is the emerged portion of the Sable Island Bank and is about $160 \mathrm{~km}$ southeast of mainland Nova Scotia, $53 \mathrm{~km}$ west of a large submarine canyon known as the Gully, and $40 \mathrm{~km}$ north of the upper edge of the continental slope (Fig 1a). The region is influenced by the northeasterly flow of the Gulf Stream passing south of Sable Island, the southwesterly flow of the Nova Scotia Current passing to its west, and the southern flow of the Labrador Current (Sutcliffe et al. 1976). A large and persistent anti-clockwise gyre is formed among these currents, and is roughly centered on Sable Island (Hannah et al. 1996, 2001). The gyre entrains floating materials such as plastic litter, petroleum residues, seaweed, bird and seal corpses, and other debris, some of which eventually washes ashore on the island.

Sable Island is located in an area with frequent marine traffic among ports in eastern Canada (the Atlantic Provinces and the St. Lawrence

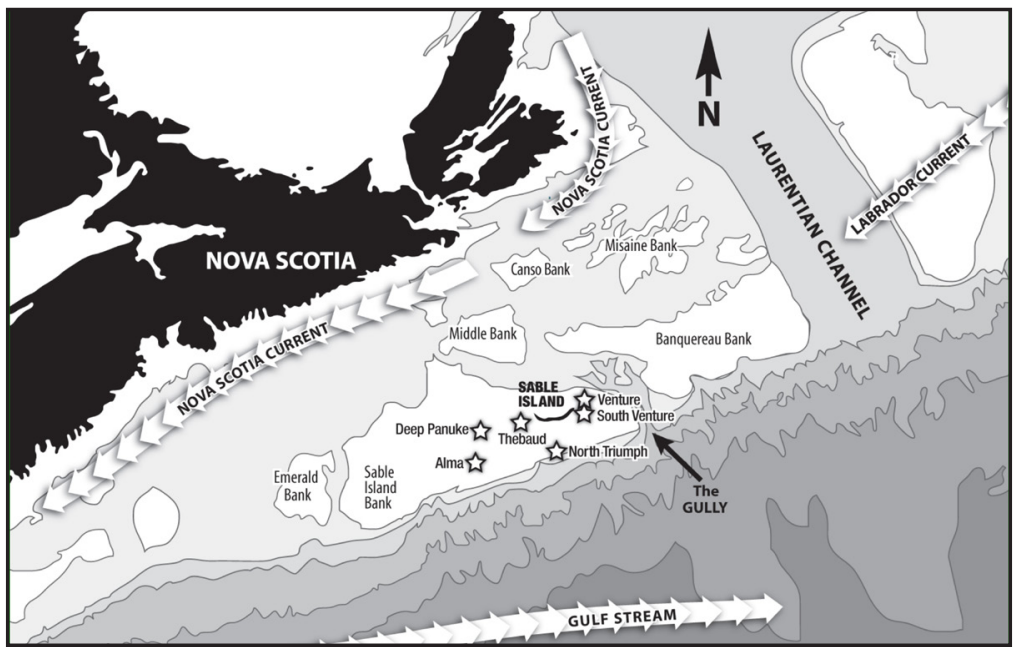

Fig 1a Nova Scotia and the Scotian Shelf region. Locations of present offshore energy installations near Sable Island are indicated by star symbol. 
Seaway), the USA, and Europe. Some of this shipping activity has been responsible for discharges of petroleum into regional waters (Chardine 1991, Cook et al. 2006, Percy \& Dewis 2006). In addition, the Sable Island Bank is at a centre of production of offshore fossil fuels. Production platforms are located to the east, south, and southwest of the island (Fig 1a). Because Sable Island is an isolated offshore location, it has been used as a monitoring station for marine litter (Lucas 1989) and beached marine mammals (Lucas \& Hooker 2000, Lucas \& Daoust 2002, Lucas \& Natanson 2010).

The earliest published reports of oiled birds on Sable Island were in 1970 following the mid-winter grounding of the coastal tanker Arrow, which released bunker-C into Chedabucto Bay, Nova Scotia (Brown et al. 1973). This observation was followed by sporadic surveys by Environment Canada personnel for beached seabirds during the 1970s (Brown et al. 1973) and early 1980s (Lock 1992), and by Zoe Lucas in 1984 and 1985-86. Since 1993, however, there has been a continuous program of beached bird surveys on Sable Island as part of the Environmental Effects Monitoring Program associated with oil and gas activity in the Sable Island Bank region. Generic identification of petroleum residues collected from the beach and feathers of bird corpses found on the island during 1996 to 2005 was reported by Lucas and MacGregor (2006). The primary goals of the present study are to establish the patterns of occurrence of beached birds at Sable Island, and to monitor long-term trends. Here we report the incidences of oiling for seabirds and waterfowl recorded during surveys on Sable Island.

\section{METHODS}

\section{Study Site}

Sable Island is approximately $45 \mathrm{~km}$ long and up to $1.5 \mathrm{~km}$ wide, and is oriented roughly west-east, with its ends curving northwards (Fig 1b). The shoreline comprises an uninterrupted sand beach. Beach width during summer varies from about $10 \mathrm{~m}$ to more than 50 $\mathrm{m}$ on the north side, and from $10 \mathrm{~m}$ to $700 \mathrm{~m}$ on the south side. The greatest width of beach on the south side occurs in two areas, one (known as the sandy plain) about $9 \mathrm{~km}$ long and up to $700 \mathrm{~m}$ wide, and another $2.5 \mathrm{~km}$ long and $450 \mathrm{~m}$ wide, both on the western half of the island. During the winter all beach areas are generally narrower, and occasionally sections are only a few meters wide at low tide. Such 


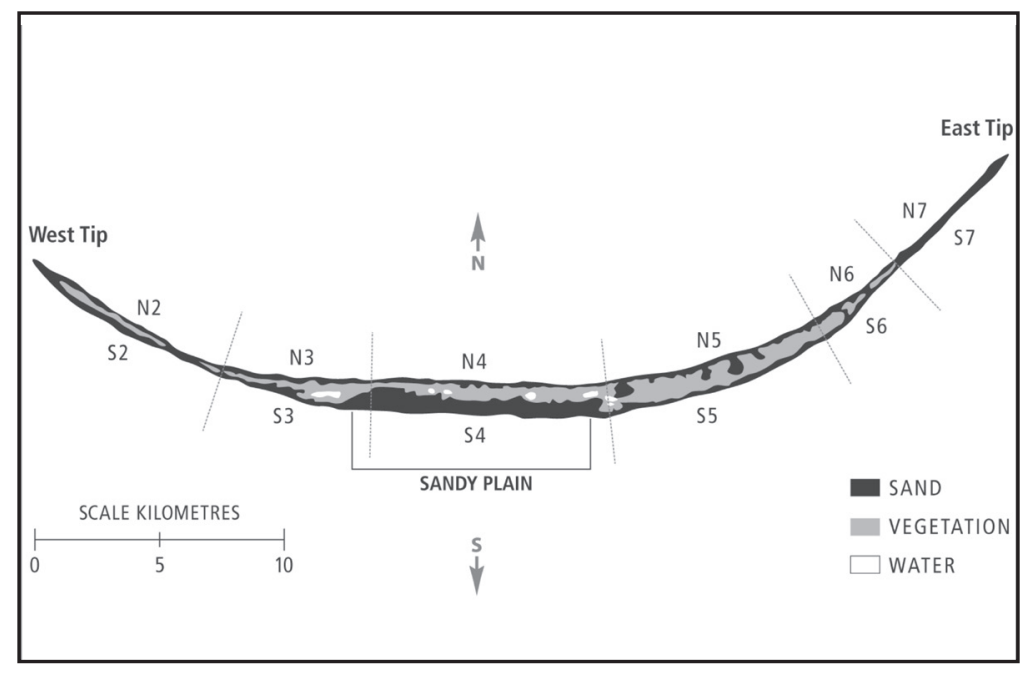

Fig 1b Sable Island. Six survey areas were established along the north and south sides. These areas roughly correspond to variations in the orientation of the beach according to the inner and outer curves of the island.

reductions in width also occur during storms throughout the year.

For the purposes of this survey the island was divided into six sections along the north and south sides (Fig 1b). These areas roughly correspond to variations in the orientation of the beach according to the inner and outer curves of the island. Between January 1993 and May 1994, only the north and south beaches backed by vegetated dunes were included in the survey program (i.e., sections s3 to s6 and $\mathrm{n} 3$ to n6, totalling $56 \mathrm{~km}$ of shoreline). Beginning in June 1994, the north and south sides of the west spit (sections s2 and n2) were added, increasing the shoreline in the study to $72 \mathrm{~km}$. In June 1998 the north and south sides of the east spit were added (sections s7 and $\mathrm{n} 7)$, so that the entire shoreline of Sable Island $(92 \mathrm{~km})$ was included in the study site.

\section{Search Protocol}

The beach was examined from the low tide line to the upper reach of storm waves, which in most areas extend to the base of the vegetated dunes. Where storm waves wash into large unvegetated breaks between dunes, and along the sandy plain, the area surveyed extended approximately $30 \mathrm{~m}$ above the high tide line. 
All surveys were conducted by the first author, once every 25-45 days as weather and beach conditions permitted. The interval between surveys exceed 45 days on 29 occasions, which is $17 \%$ of the total surveys. The longest of these were a 96-day interval between surveys in January and April 1994, and an 81-day interval in October and December 2000. Conditions that affected the timing of surveys included narrow beach profiles and flooding after winter and tropical storm events, snow and ice cover, and grey seal (Halichoerus grypus) breeding colonies that occasionally impeded travel on, and search of, the beach.

Surveys were conducted by travelling slowly back and forth between the water's edge and the upper reach of storm waves on an all-terrain vehicle. At the start of each survey, the beach was examined to determine the position of highest water since the last survey. Depending upon visibility and beach conditions, each survey took three to five days to complete. In some cases the beach was flat and clear of debris. At other times, however, the beach was littered with debris, seaweed wrack, and chunks of eroded peat, with irregular topography caused by high winds and waves.

\section{Examination and Reporting of Bird Corpses}

All bird corpses and fragments found during the surveys were examined, and either marked with coloured wire or removed from the beach. Corpses of young gulls from the island's Herring Gull (avian binomials are given in Table 1) and Great Black-backed Gull colonies still being fed by parents, were not included because this age group is not likely to be exposed to pollution at sea. Separated right and left wings of the same species and age found in the same section of beach were counted as one corpse. Species identification, corpse condition (completeness and freshness), any obvious external injury, presence and extent of oiling or entanglement, and scientific markings such as leg bands were recorded for each corpse.

The presence of oil was recorded using a protocol similar to that employed in studies in other regions (Chardine \& Pelly 1994, Camphuysen 1998, Wiese \& Ryan 1999, Žydelis et al. 2006). The oiling rate was calculated using only complete or largely intact corpses (i.e., having $75 \%$ of all feather groups present for examination). The presence and degree of oiling of complete corpses was recorded as a code using a four-point scale: (0) clean plumage; (1) slight surface oiling, or $<10 \%$ of the body oiled; (2) moderate oil, penetrating to the 
Table 1 List of 52 species of seabird and waterfowl represented by corpses recovered during beach surveys on Sable Island, 1993-2009.

\begin{tabular}{|c|c|c|}
\hline Family and Species & Percent of total & Total cor \\
\hline Gaviidae & 0.2 & \\
\hline Red-throated Loon (Gavia stellata) & & 2 \\
\hline Common Loon (Gavia immer) & & 19 \\
\hline Podicipedidae & 0.1 & \\
\hline Red-necked Grebe (Podiceps grisegena) & & 15 \\
\hline Procellariidae & 21.1 & \\
\hline Northern Fulmar (Fulmarus glacialis) & & 510 \\
\hline Cory's Shearwater (Calonectris diomedea) & & 14 \\
\hline Greater Shearwater (Puffinus gravis) & & 1,304 \\
\hline Manx Shearwater (Puffinus puffinus) & & 3 \\
\hline Sooty Shearwater (Puffinus griseus) & & 455 \\
\hline Hydrobatidae & 0.4 & \\
\hline $\begin{array}{l}\text { Leach's Storm-petrel (Oceanodroma leucorhoa) } \\
\text { petrel species }{ }^{2}\end{array}$ & & $\begin{array}{l}29 \\
15\end{array}$ \\
\hline Phaethontidae & 0.1 & \\
\hline Red-billed Tropicbird (Phaethon aethereus) & & 2 \\
\hline White-tailed Tropicbird (Phaethon lepturus) & & 4 \\
\hline Phalacrocoracidae & 0.1 & \\
\hline Great Cormorant (Phalacrocorax carbo) & & 8 \\
\hline $\begin{array}{l}\text { Double-crested Cormorant (Phalacrocorax auritus) } \\
\text { cormorant species }{ }^{2}\end{array}$ & & $\begin{array}{l}2 \\
1\end{array}$ \\
\hline Sulidae & 2.5 & \\
\hline Northern Gannet (Morus bassanus) & & 269 \\
\hline Anatidae & 0.4 & \\
\hline Canada Goose Branta canadensis & & 4 \\
\hline Snow Goose (Chen caerulescens) & & 1 \\
\hline Wood Duck (Aix sponsa) & & 3 \\
\hline Mallard (Anas platyrhynchos) & & 1 \\
\hline American Black Duck (Anas rubripes) & & 9 \\
\hline Blue-winged Teal (Anas discors) & & 1 \\
\hline Ring-necked Duck (Aythya collaris) & & 1 \\
\hline Common Eider (Somateria mollissima) & & 4 \\
\hline Long-tailed Duck (Clangula hyemalis) & & 2 \\
\hline Black Scoter (Melanitta nigra) & & 1 \\
\hline White-winged Scoter (Melanitta fusca) & & 1 \\
\hline $\begin{array}{l}\text { Red-breasted Merganser (Mergus serrator) } \\
\text { scaup species }{ }^{2}\end{array}$ & & $\begin{array}{r}16 \\
4\end{array}$ \\
\hline Rallidae & $<0.1$ & \\
\hline American Coot Fulica americana & & 1 \\
\hline Laridae & 14.3 & \\
\hline Long-tailed Jaeger (Stercorarius longicaudus) & & 1 \\
\hline Parasitic Jaeger (Stercorarius parasiticus) & & 1 \\
\hline $\begin{array}{l}\text { Pomarine Jaeger (Stercorarius pomarinus) } \\
\text { jaeger species }{ }^{2}\end{array}$ & & $\begin{array}{l}5 \\
2\end{array}$ \\
\hline South Polar Skua (Stercorarius maccormicki) & & 3 \\
\hline Great Skua (Stercorarius skua) & & 3 \\
\hline Bonaparte's Gull (Larus philadelphia) & & 2 \\
\hline Laughing Gull (Larus atricilla) & & 5 \\
\hline California Gull (Larus californicus) & & 1 \\
\hline
\end{tabular}


Table 1 Continued

\begin{tabular}{|c|c|c|}
\hline Family and Species & Percent of total & Total corpses $^{1}$ \\
\hline Herring Gull (Larus argentatus) & & 271 \\
\hline Iceland Gull (Larus glaucoides) & & 73 \\
\hline Glaucous Gull (Larus hyperboreus) & & 5 \\
\hline Lesser Black-backed Gull (Larus fuscus) & & 1 \\
\hline Great Black-backed Gull (Larus marinus) & & 759 \\
\hline Black-legged Kittiwake (Rissa tridactyla) & & 386 \\
\hline Sandwich Tern (Sterna sandvicensis) & & 2 \\
\hline Common Tern (Sterna hirundo) & & 28 \\
\hline Arctic Tern (Sterna paradisaea) & & 1 \\
\hline Sooty Tern (Sterna fuscata) & & 1 \\
\hline Black Skimmer (Rynchops niger) & & 2 \\
\hline tern species ${ }^{2}$ & & 3 \\
\hline Alcidae & 60.8 & \\
\hline Common Murre (Uria alge) & & 221 \\
\hline Thick-billed Murre (Uria lomvia) & & 2,024 \\
\hline Razorbill (Alca torda) & & 112 \\
\hline Dovekie (Alle alle) & & 1,888 \\
\hline Black Guillemot (Cepphus grille) & & 13 \\
\hline Atlantic Puffin (Fratercula arctica) & & 538 \\
\hline large alcids ${ }^{2}$ & & 1,810 \\
\hline Total Corpses & & 10,862 \\
\hline
\end{tabular}

1 Includes total number of specimens, both complete and partial corpses.

2 Specimens not identified to species.

base of feathers, $10-25 \%$ oiled; (3) heavy oil, $>25 \%$ oiled. Incomplete corpses, with less than $75 \%$ of the plumage present, were categorized as Code 4 . We recorded the presence of oil on incomplete corpses, but except where noted the oiling rates presented are based on complete and largely intact corpses, so they are comparable with protocols and results reported in other published studies of this type.

On Sable Island, corpses may be rapidly buried by windblown sand, and then exposed again days to months later. Consequently, some corpses recorded during surveys were up to several months old, having been buried and missed during previous surveys. When possible, the month of beaching was estimated based on the freshness of tissues, degree of scavenging, effects of sandblasting on feathers, or marking of corpses between surveys. Except for fresh specimens, most corpses found in surveys conducted during the first week of the month were considered to have beached during the preceding month (e.g., a bird found during a survey done on May 4th would be considered to be an April corpse). 
For corpses of large alcids that were comprised of only wings and few or no other body parts, or largely intact corpses missing the head and/or tail feathers, it was not practical to distinguish among Razorbill, Common Murre, and Thick-billed Murre, and these were recorded as "large alcids".

In addition to oil on bird corpses, the occurrence and distribution of oil on the beach was recorded during surveys between 2006 and 2009. Events occurring prior to 2006 were reported by Lucas \& MacGregor (2006).

\section{Earlier Studies}

Prior to the 1993-2009 program, three short-term beach surveys were conducted in response to particular oiling events. These were: January 1975; February-March 1984 during the Shell-Uniacke G72 gas well blowout; and late December 1986. Also, the beach was surveyed in February, June, and October of 1985; and in February, April, May, June, September, and December of 1986. These surveys were restricted to areas within sections s3 to s6 and n3 to n6 (Fig 1b). Although the intervals between surveys in 1985-1986 varied from five weeks to several months, and Larus gull corpses were not recorded, the beach survey methods were otherwise similar to those of the 1993-2009 program.

\section{Collection and Analyses of Oil Residues}

Samples of petroleum residues were collected from corpse plumage and from the beach to represent pollution occurring on various locations of the island's shoreline (i.e., the north and south sides, and east and west ends), and on various species and/or groups of birds. Samples were packaged in aluminum foil or in glass jars with foil covers, kept frozen, and delivered to a laboratory for gas chromatographic analysis (MacGregor \& Associates, Halifax, NS).

\section{Statistical analysis of annual trends}

To assess annual trends in corpse density (oiled and unoiled) and oiling rate, data from individual species were pooled for shearwaters, gulls, and alcids. Northern Fulmars were analyzed separately because, unlike the other species, they had adequate sample sizes for analysis but could not be readily pooled into any of these taxonomic categories. Annual trends were first analyzed with generalized linear models (with Poisson links for densities and binomial links for oiling rate), but yielded excessive overdispersion even after corrections. Conse- 


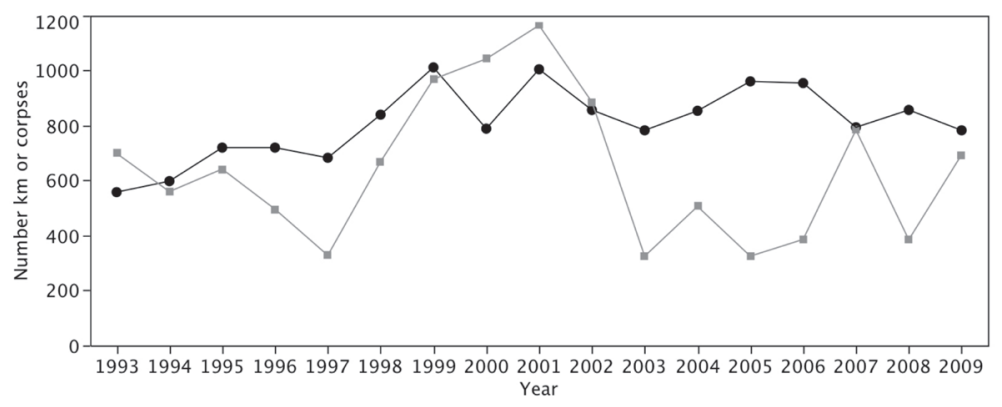

Fig 1c Total number of linear kilometres surveyed per year (black line), and total number of seabird and waterfowl corpses (all species and codes combined) recovered per year (grey line).

quently the data were transformed (log transformation for densities, arcsine transformation for oiling rate) and analyzed by least squares regression. Transformation yielded residuals with acceptably normal distributions (Shapiro-Wilk tests, $\mathrm{P}>0.05$ ).

\section{RESULTS}

\section{Numbers of Corpses}

A total of 171 surveys covering 13,770 linear km of beach (Fig 1c) was conducted between January 1993 and December 2009, and 10,884 bird corpses, representing 64 species, were found. Of these, 12 species (totalling 22 specimens) were landbirds or herons, which are birds not likely exposed to marine petroleum in the study area and are not considered further. The remainder (Table 1) was comprised mostly of three families: fulmar and shearwaters (Procellariidae), jaegers, gulls, and terns (Laridae), and alcids (Alcidae). The species with the highest frequencies of occurrence were Northern Fulmar, Herring Gull, and Great Black-backed Gull, being found in 75\%, 67\%, and $89 \%$ of surveys, respectively.

Fifty-two percent of seabird and waterfowl corpses recovered were complete (having $>75 \%$ of all feather groups remaining). Complete corpses comprised $69 \%$ of shearwater specimens, $75 \%$ of Larus gulls, and $43 \%$ of alcids (Table 2). Of the 1,835 of corpses that could not be identified to species, $99 \%$ were large alcids and the rest were cormorants, storm-petrels, scaups, jaegers, and terns. Of 2,357 corpses of large alcids identified to species, $85.8 \%$ were Thick-billed Murre, 
9.4\% Common Murre, and 4.8\% Razorbill. If it is assumed that these species occurred in a similar proportion among the 1,810 unidentified "large alcids," then the total estimated number of Thick-billed Murres found during the surveys was 3,578, Common Murres 391, and Razorbills 198. Thus, overall, Thick-billed Murres would have comprised 33\% of all corpses recovered during the 1993-2009 survey.

\section{Seasonal Trends}

The seasonal average linear density of bird corpses for all species combined (complete and incomplete) across the 17 year sampling period, was $1.306 / \mathrm{km}$-month in late autumn and winter (NovemberApril), and 0.389/km-month in late spring and summer (May-October). Monthly variations in corpse numbers showed strong seasonal trends for some bird groups and species. Of the three main groups, $82 \%$ of shearwaters (Fig 2a) occurred in June and July, 50\% of Larus gulls (Fig 2b) in January through April, and $98 \%$ of alcids (Fig 2c) in December through May.

Within gull and alcid groups, however, there were species-specific patterns. Herring Gulls showed some seasonality in occurrence, with $67 \%$ found during the March-July period when this species is establishing nests and raising young on the island. Great Black-backed Gulls also nest on the island, but $61 \%$ of corpses occurred in December

Fig 2 Seasonal occurrence of selected bird groups and species. All corpses (Codes $0-4)$, grey line; and complete corpses (Codes $0-3)$, black line.

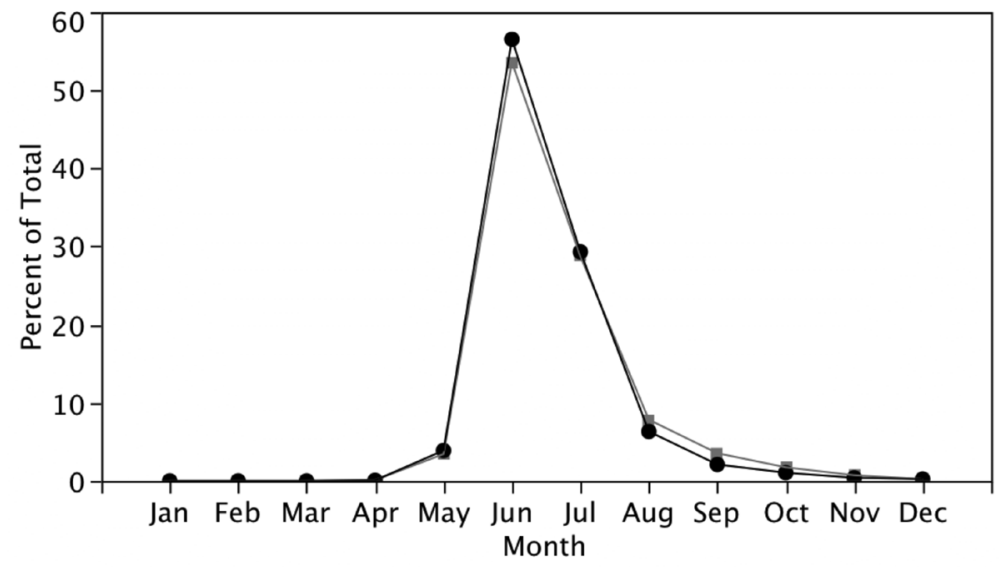

Fig 2a Shearwaters (Sooty, Cory's, and Greater). All corpses $(n=1,773)$; and complete corpses $(n=1,231)$. 


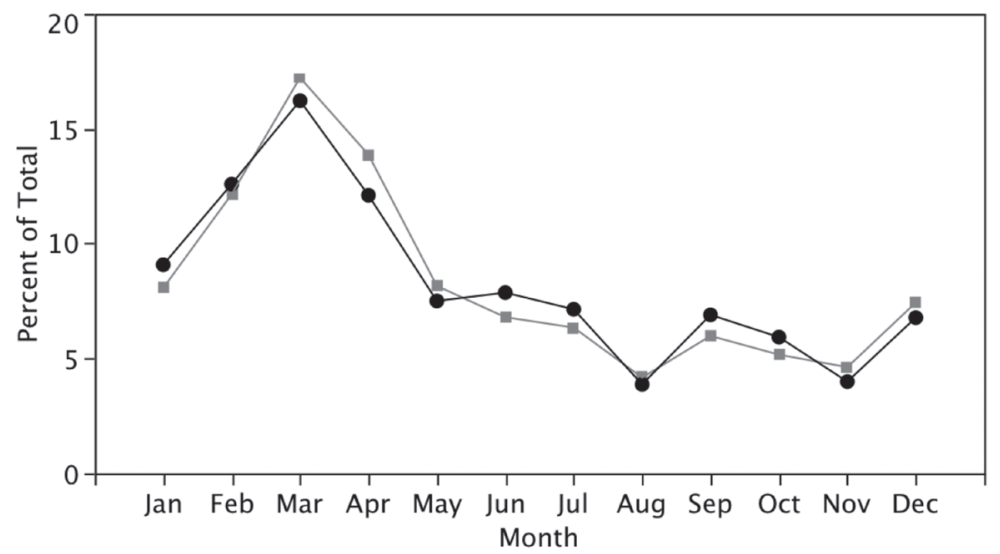

Fig 2b Larus gulls (Iceland, Herring, and Great Black-backed). All corpses ( $\mathrm{n}=1,103)$; complete corpses $(n=826)$.

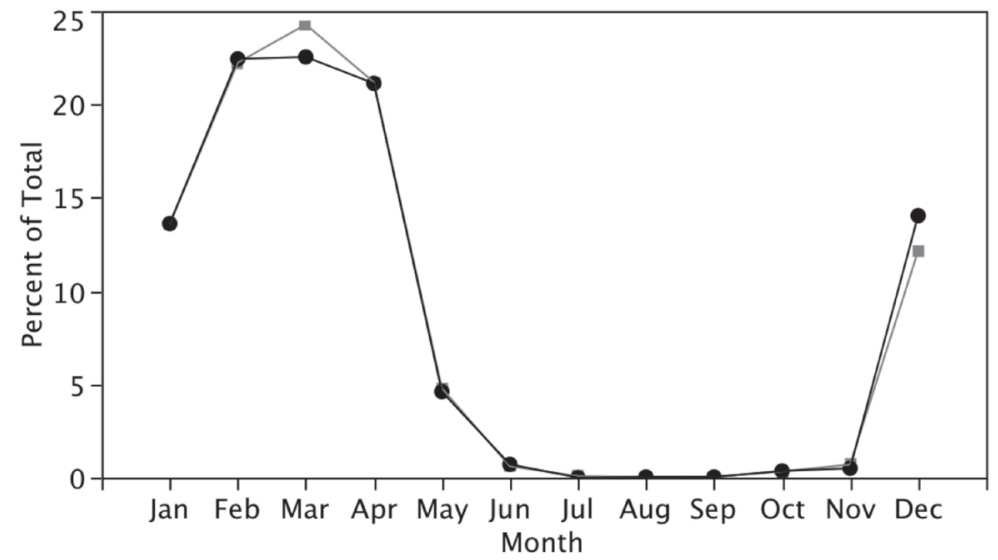

Fig 2c Alcids (Common \& Thick-billed Murres, Razorbill, unidentified large alcids, Dovekie, and Atlantic Puffin). All corpses $(n=6,593)$; and complete corpses $(\mathrm{n}=2,821)$.

through April. Most Black-legged Kittiwakes occurred during late fall through to early spring. The seasonal occurrence of large alcids was dominated by Thick-billed Murre, which greatly outnumbered Razorbill and Common Murre. Dovekie and Atlantic Puffin corpses peaked earlier in the winter. Although Northern Fulmar was recorded throughout the year, $69 \%$ of corpses were found in February through June (Fig 2d), and $71 \%$ of Northern Gannet corpses in OctoberDecember (Fig 2e). Only 5 of the 52 seabird and waterfowl species occurred in all months of the year during the 1993-2009 surveys: 


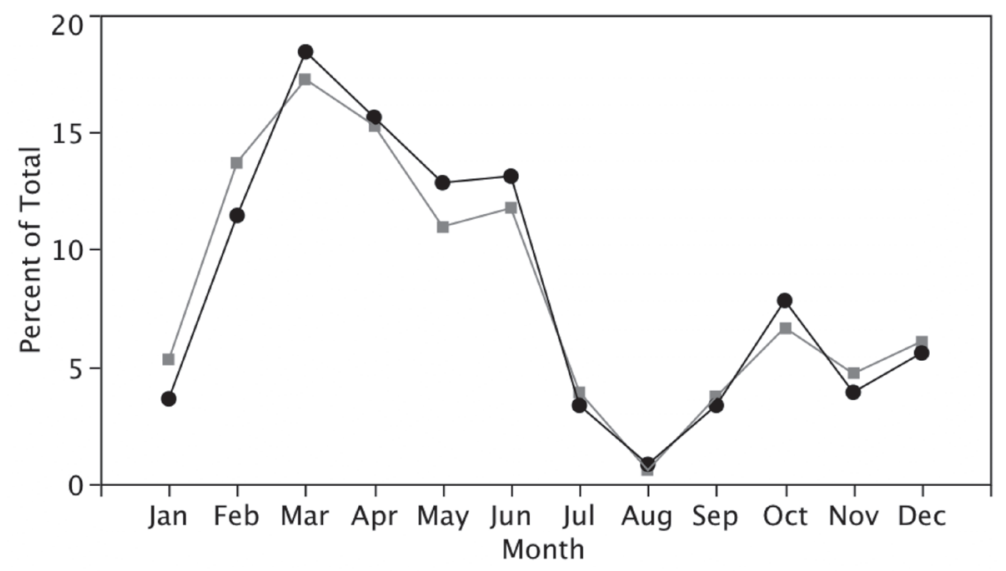

Fig 2d Northern Fulmar. All corpses ( $\mathrm{n}=510)$; complete corpses $(\mathrm{n}=358)$.

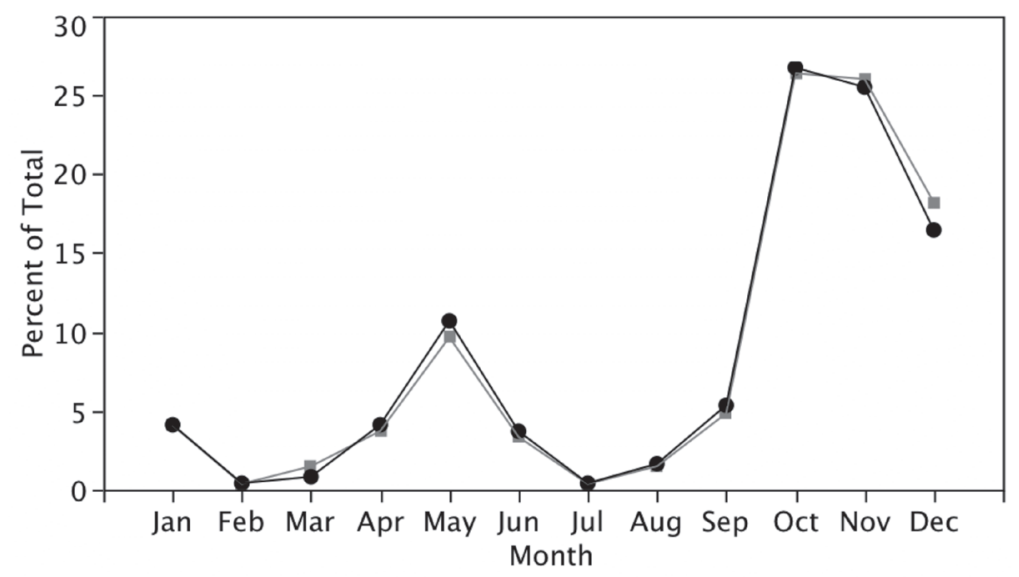

Fig 2e Northern Gannet. All corpses $(n=269)$; and complete corpses $(n=243)$.

Northern Fulmar, Northern Gannet, Herring Gull, Great Black-backed Gull, and Black-legged Kittiwake.

\section{Linear Density of Corpses}

The total corpse density (complete and incomplete corpses combined) averaged over the 17 -year study period was 0.790 per km-year, with the annual density ranging from a low of $0.338 / \mathrm{km}$ in 2005 to a high of $1.322 / \mathrm{km}$ in 2000 . The 17 -year average corpse densities for the most abundant groups and species were: 
- $\quad$ shearwaters $0.129 / \mathrm{km}$ (annual range 0.022 to $0.365 / \mathrm{km})$ (Fig 3a)

- Larus gulls $0.080 / \mathrm{km}(0.039$ to $0.156 / \mathrm{km})$ (Fig 3b)

- alcids $0.479 / \mathrm{km}(0.105$ to $1.047 / \mathrm{km})$ (Fig 3c)

- Northern Fulmar 0.037/km (0.006 to 0.081/km) (Fig 3d)

- Northern Gannet $0.020 / \mathrm{km}(0.005$ to $0.042 / \mathrm{km})$

- Black-legged Kittiwake 0.028/km $(0.005 / \mathrm{km}$ to $0.054 / \mathrm{km})$

Except for alcids (Fig 3c), the annual density of total corpses and complete corpses did not show significant trends within the main bird groups (Figs 3a, 3b \& 3d).

Fig 3 Annual density of selected bird groups and species, oiled and unoiled corpses combined. Tests of annual trends (on transformed data; see text). All corpses (codes 0-4, grey line); complete corpses (codes 0-3, black line).

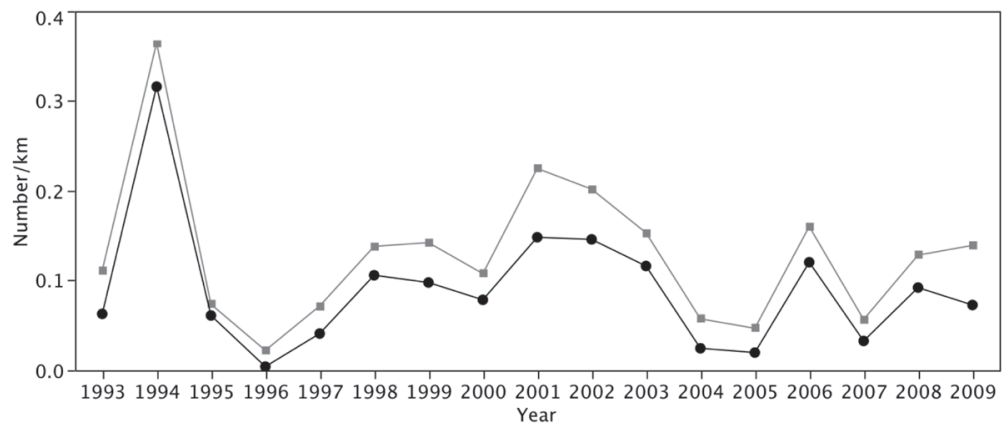

Fig 3a Shearwaters. Tests of annual trends: all Corpses, $\mathrm{F}_{1,15}=0.32, \mathrm{P}=0.58$; complete corpses, $\mathrm{F}_{1,15}=0.68, \mathrm{P}=0.42$.

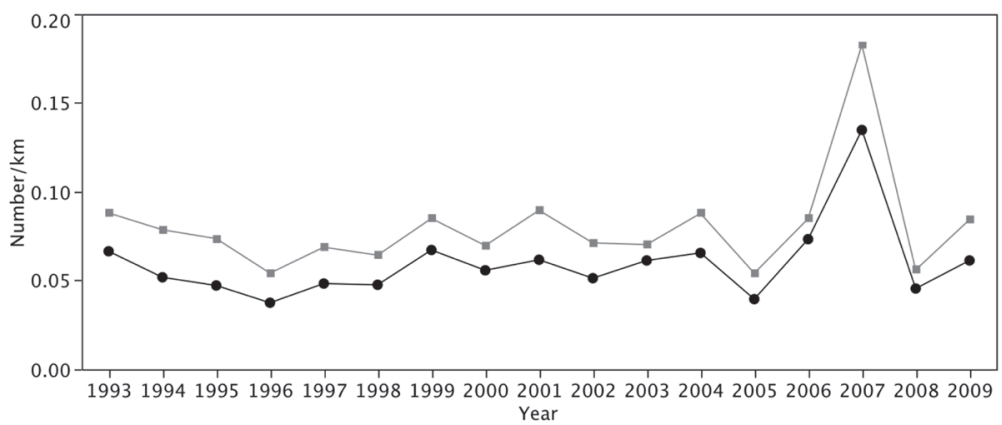

Fig 3b Larus gulls. Tests of annual trends: all corpses, $\mathrm{F}_{1,15}=1.03, \mathrm{P}=0.33$; complete corpses, $\mathrm{F}_{1,15}=2.11, \mathrm{P}=0.17$. 


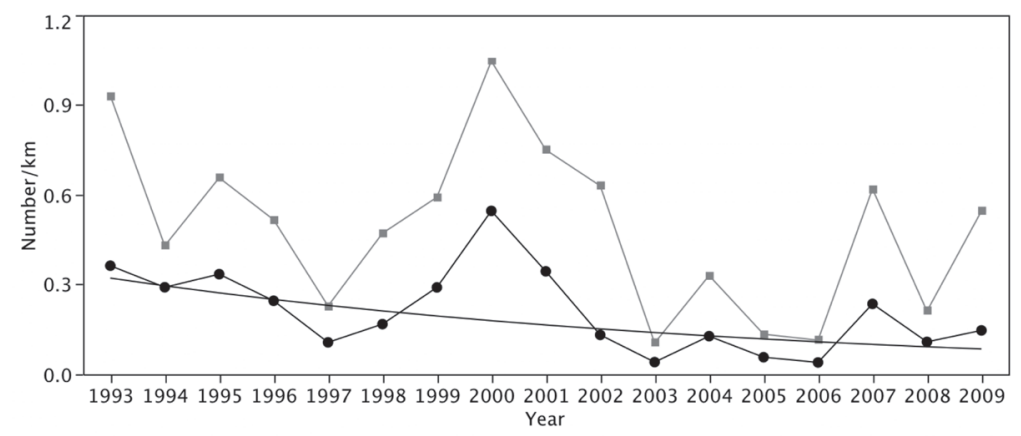

Fig 3c Alcids. Tests of annual trends: all corpses, $\mathrm{F}_{1,15}=3.01, \mathrm{P}=0.10$; complete corpses, $\mathrm{F}_{1,15}=6.18, \mathrm{P}=0.03$. Trend line fitted to transformed data (see text).

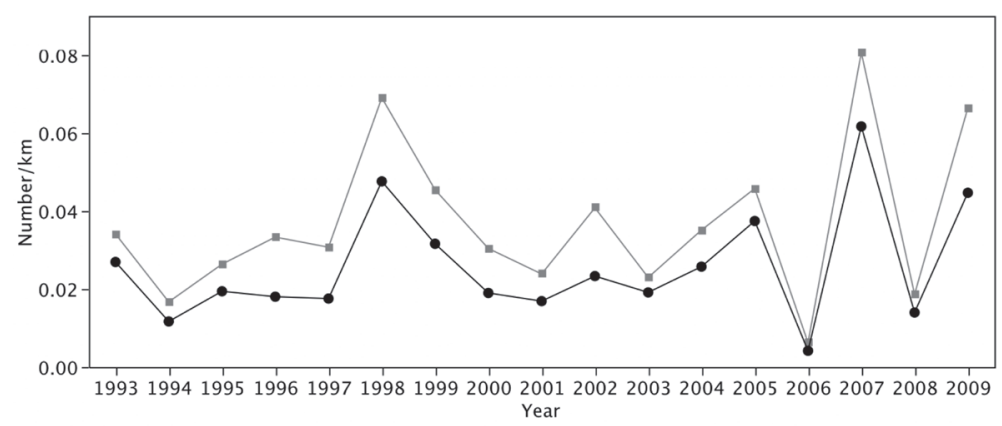

Fig 3d Northern Fulmar. Tests of annual trends: all corpses, $\mathrm{F}_{1,15}=1.28, \mathrm{P}=0.28$; complete corpses, $\mathrm{F}_{1,15}=0.90, \mathrm{P}=0.36$.

\section{Spatial Distribution of Corpses}

Fifty-nine percent of all corpses recovered during 1993-2009 were found on the north beach and $41 \%$ on the south. The linear density of corpses was $0.956 / \mathrm{km}$ and $0.628 / \mathrm{km}$ on the north and south beaches, respectively. However, when bird groups were examined separately, there were larger differences in corpse density of shearwaters and alcids between the north and south sides of the island. More than $75 \%$ of shearwaters occurred on the south side, while $71 \%$ of alcids were on the north. Razorbill was the only alcid species that did not occur more often on the north beach, with $47 \%$ recovered from the north side. Among other species, $54 \%$ of fulmars were found on the north beach, as were $47 \%$ of gannets, $56 \%$ of Larus gulls, and $64 \%$ of kittiwakes. 


\section{Incidence of Oil Contamination}

Oiled corpses were recorded for 15 of the 52 seabird and waterfowl species found in the 1993-2009 surveys (Table 2). Of the 37 species not oiled, 30 were represented by $\leq 5$ specimens and some are only incidental in the study region (e.g., Red-billed Tropicbird, White-tailed Tropicbird, California Gull, Lesser Black-backed Gull, Sandwich Tern, and Black Skimmer) (Table 1). Sooty Shearwater was the only species found in large numbers (i.e., 455 corpses) of which none were oiled.

Oiled corpses, complete and incomplete combined, occurred in all months, but $96 \%$ were in winter (November through April), and only $4 \%$ in summer (May through October) (Fig 4a). The preponderance of alcids in winter and early spring resulted in this seasonal peak of oiled corpses.

The proportion of oiled corpses (based on complete corpses, Codes 0 - 3), all species combined, was 29\%, ranging from $70 \%$ (165 of 236) in 1996 to $1.4 \%$ (4 of 277) in 2009. Shearwaters (Fig 5a) and Larus gulls (Fig 5b) had the lowest overall oiling rate (3\% of complete corpses were oiled), while alcids showed the highest rate (54\% of complete corpses, Table 2, Fig 5c).

The extent of oiling on each corpse varied across species. As a group, alcids were typically moderately to heavily affected, with $55 \%$ being oiled on $>25 \%$ of the body surface (Fig $4 \mathrm{~b}$ ). Some

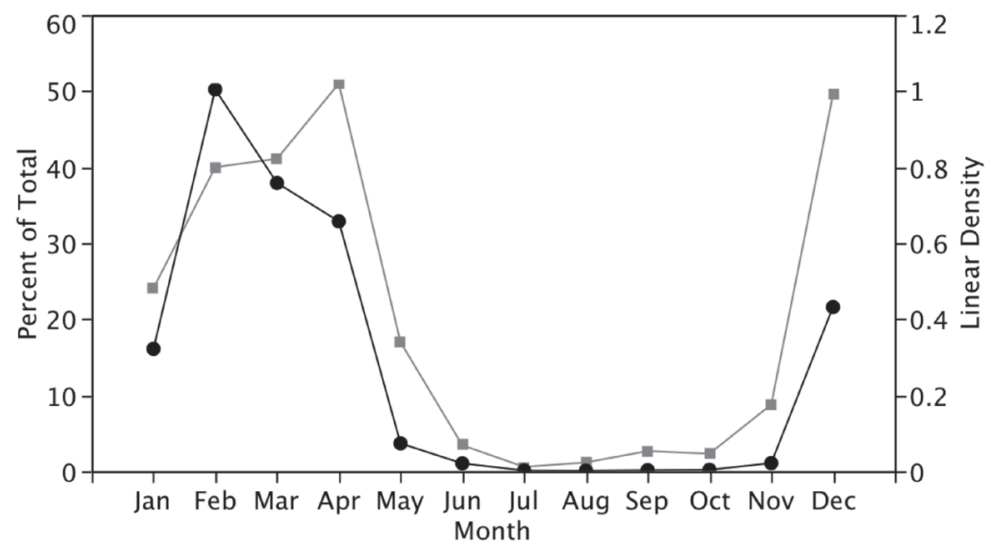

Fig 4a Seasonal incidence of oiling for species found oiled and represented by $\geq 10$ corpses, complete and incomplete combined (see Table 2). Proportion of total corpses oiled (percent, grey line), and number of oiled corpses per kilometre (linear density, black line). 


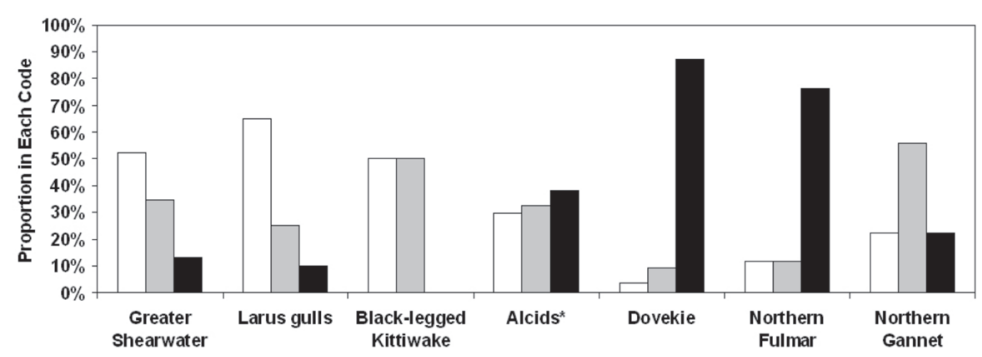

Fig 4b Proportions of the total samples of 7 taxa of oiled birds in 3 categories of oiling (proportion of body surface area oiled). Code $1(<10 \%)$ white; Code $2(10-25 \%)$ grey; Code 3 (>25\%) black. *Alcid group does not include Dovekie.

Fig 5 Annual incidence of oiling for selected bird groups and species (complete corpses). Oiling rate (proportion of corpses oiled, grey line) compared with linear density of oiled corpses (number of oiled corpses/km, black line). For significant trends and those approaching statistical significance, trend lines were fitted with transformed data (see text).

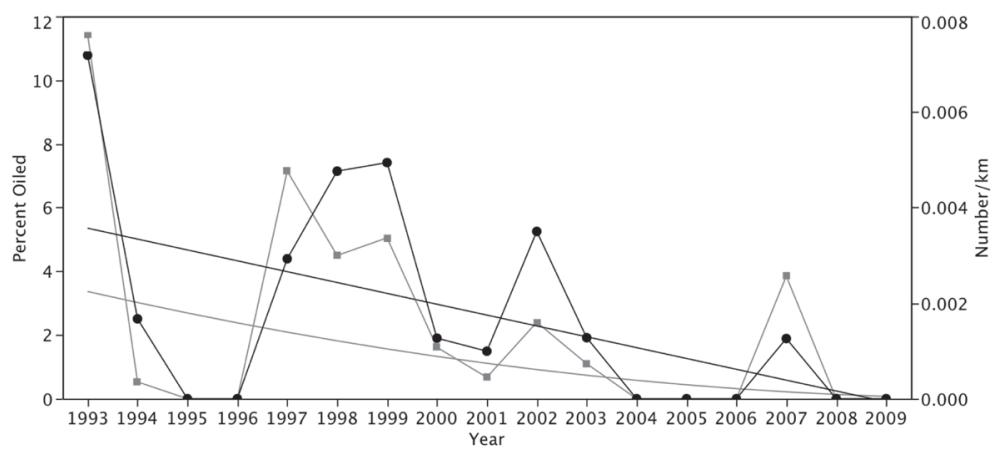

Fig 5a Shearwaters $(n=1231)$. Oiling Rate $\mathrm{F}_{1,15}=3.67, \mathrm{P}=0.07$; Linear Density $\mathrm{F}_{1,15}=5.76$, $\mathrm{P}=0.03$.

complete corpses were entirely covered in a thick coating of heavy oil, usually with a harder outer crust that indicated weathering at sea. Of the 285 such corpses, $99 \%$ were Dovekies. Of non-alcid species, only Northern Fulmar tended to be heavily oiled, with 13 of 17 oiled complete corpses having oil on $>25 \%$ of the body, and three of these were entirely coated. The proportion of corpses covered in a heavy coating of oil declined from an average of $24 \%$ in the 1990 s, to $1.9 \%$ in 2000 and $8.3 \%$ in 2001, and none found afterward.

The annual proportion of unoiled complete corpses (Code 0) for the three main bird groups did not show a significant change over the 17 years of the study (all P > 0.05; Fig 6). Both the density of oiled corpses and oiling rate, however, declined significantly for alcids and 


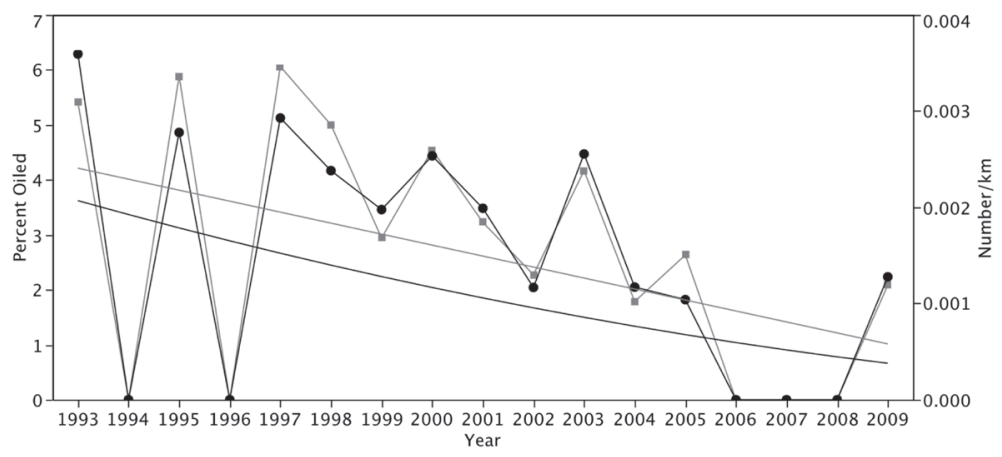

Fig 5b Larus gulls ( $\mathrm{n}=826$ ). Oiling Rate $\mathrm{F}_{1,15}=2.21, \mathrm{P}=0.16$; Linear Density $\mathrm{F}_{1,15}=4.46, \mathrm{P}=0.05$.

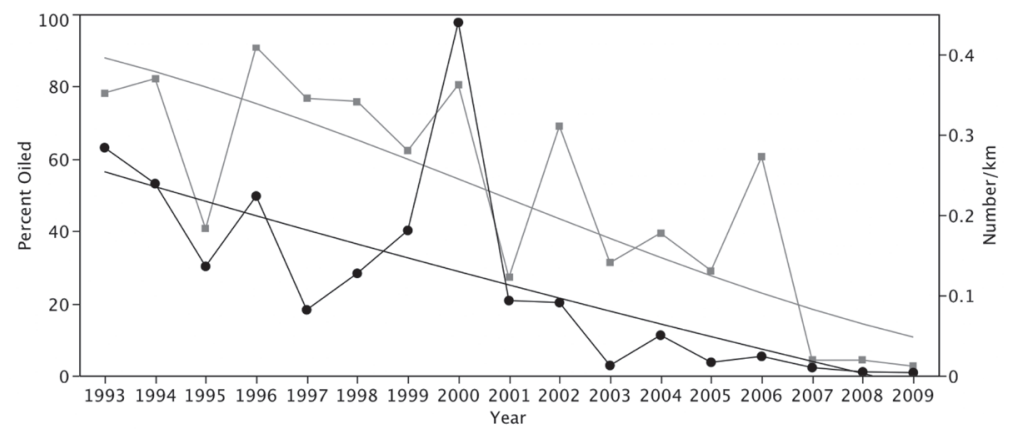

Fig 5c Alcids $(n=2,821)$. Oiling Rate $\mathrm{F}_{1,15}=25.34, \mathrm{P}=0.0001$; Linear Density $\mathrm{F}_{1,15}=16.94$, $\mathrm{P}=0.0009$.

fulmars (Figs 5c \& 5d), and in shearwaters and gulls the trends showed a weak tendency $(\mathrm{P} \leq 0.16)$ toward a decline (Figs 5 a $\& 5 b)$. Speciesspecific changes in the oiling rate, although not showing statistically significant negative trends, were evident in Razorbill, Common and Thick-billed Murre, Dovekie, Atlantic Puffin, and unidentified large alcids (Figs 5e, 5f, 5g, 5h, 5i \& 5j). Further, the average species specific oiling rates for the most abundant species (Table 2) during the last five years of the study were markedly lower than the long-term annual averages. Similarly, the overall average oiling rate for all species combined (Table 2) during the last five years was $4.4 \%$ compared with $28.9 \%$ for the 17 years of the survey program.

No oil slicks were observed during the survey program, and no beached oil in the form of pelagic tar particles was recorded during surveys conducted in 2006 through 2009. 


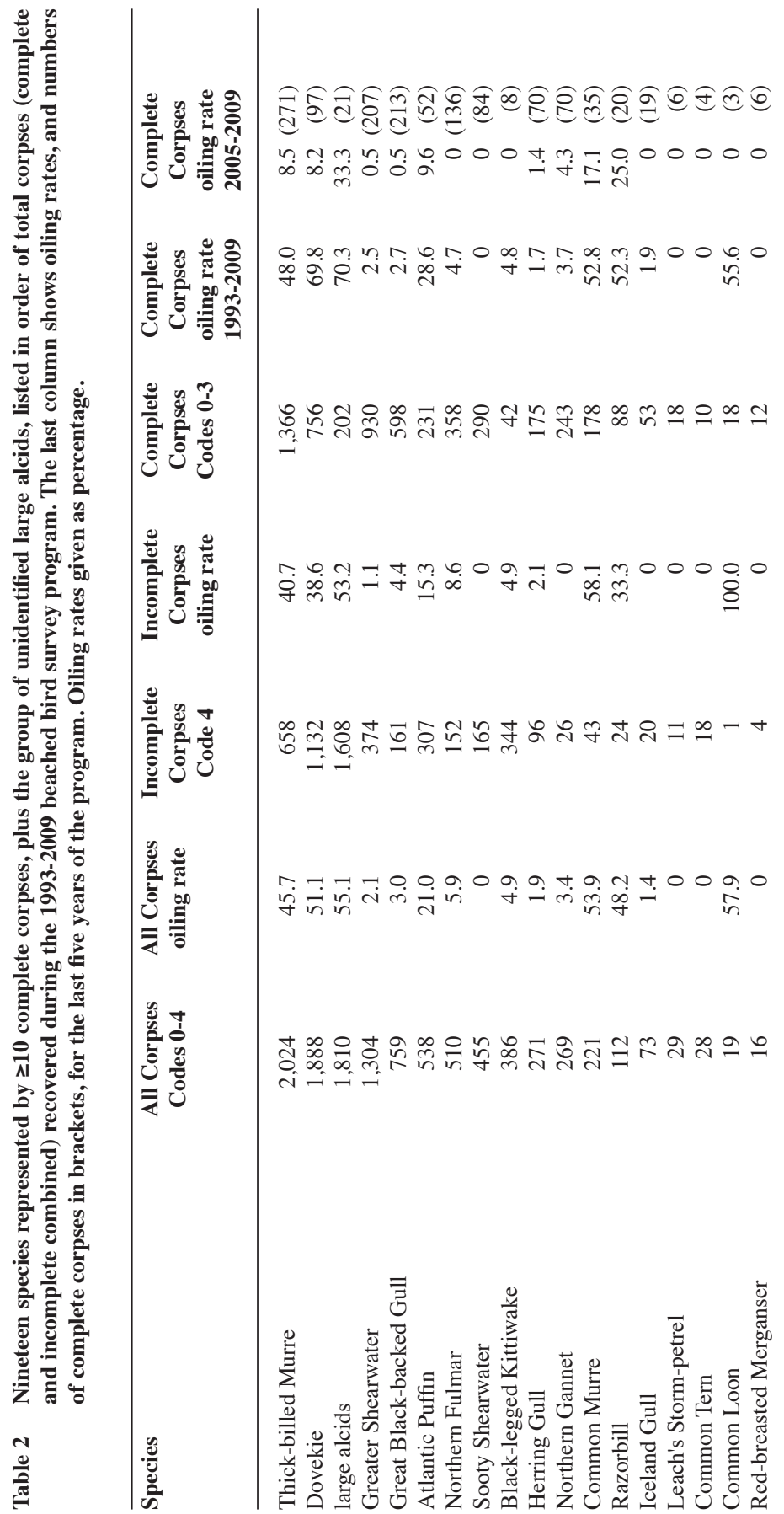




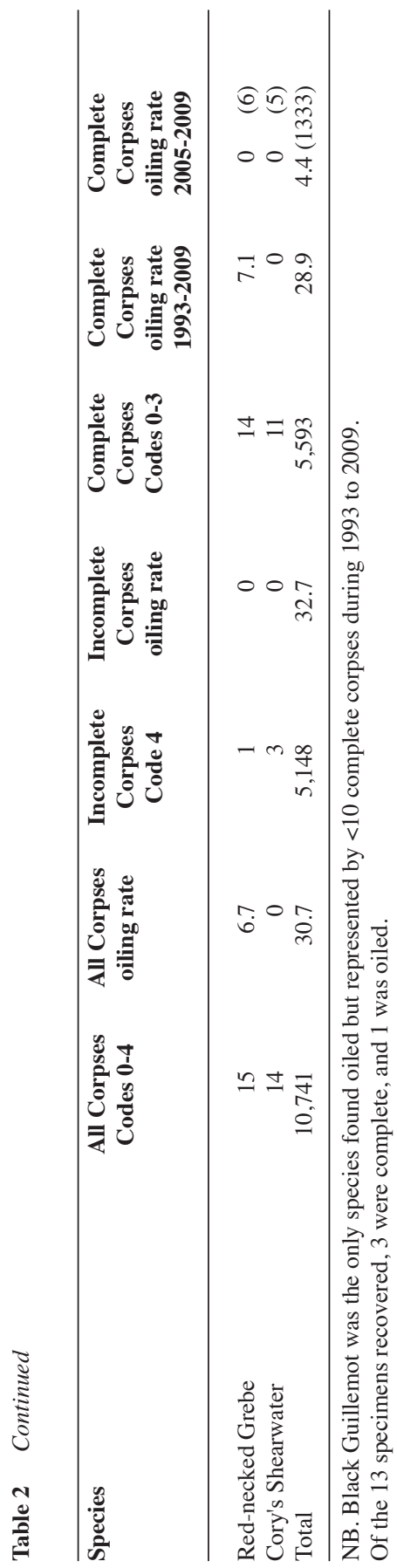




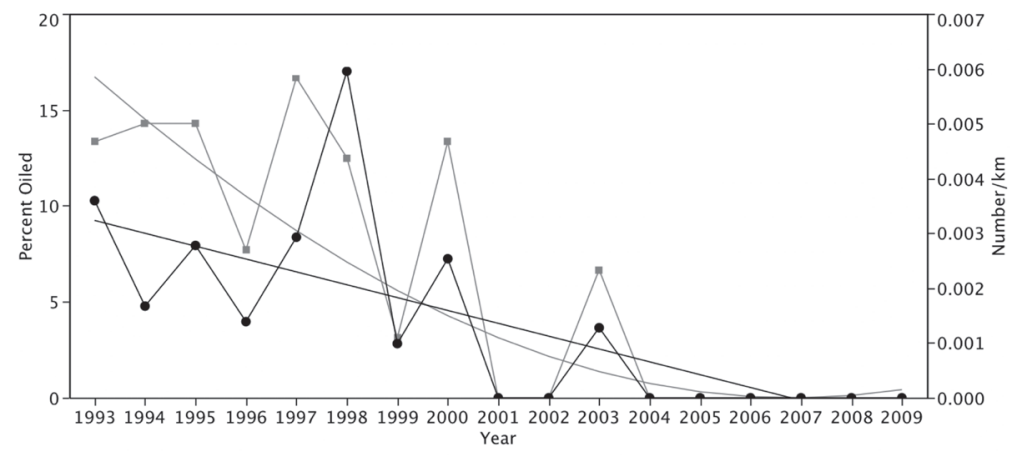

Fig 5d Northern Fulmar $(n=358)$. Oiling Rate $\mathrm{F}_{1,15}=37.56, \mathrm{P}=0.00001$; Linear Density $\mathrm{F}_{1,15}=13.71, \mathrm{P}=0.0021$.

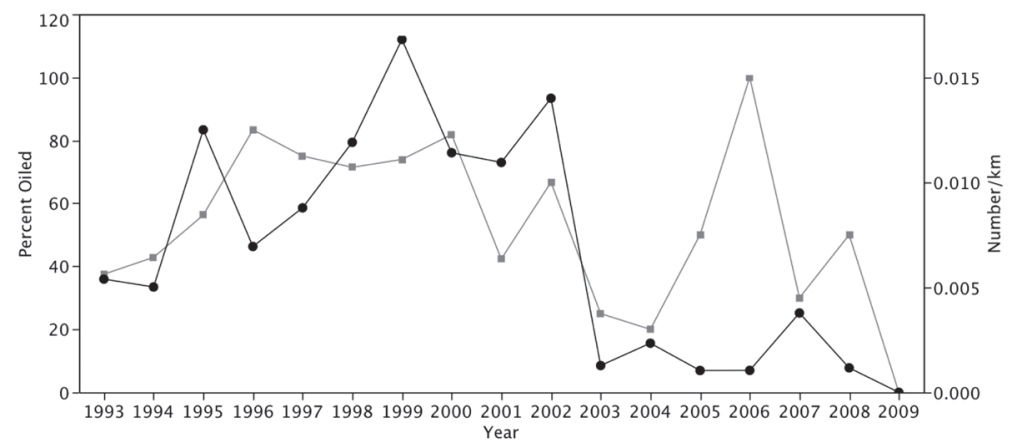

Fig 5e Common Murre $(\mathrm{n}=178)$.

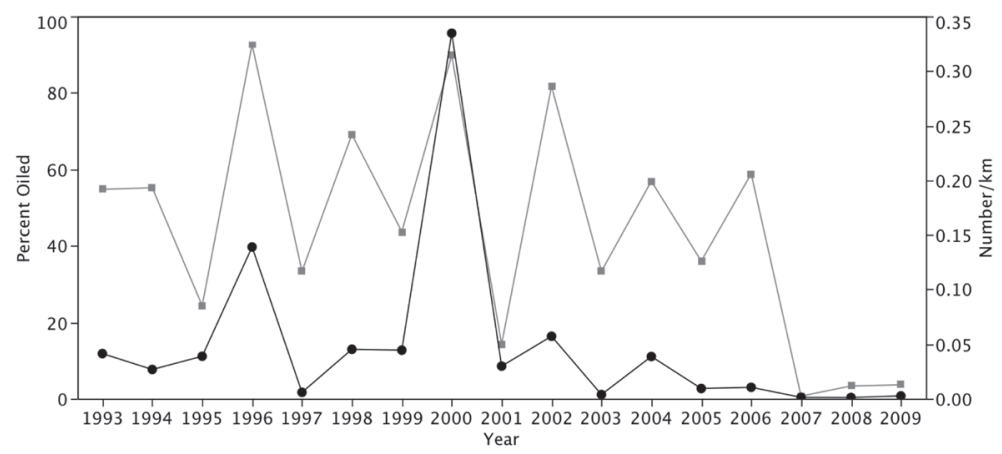

Fig $5 f$ Thick-billed Murre $(\mathrm{n}=1,366)$. 


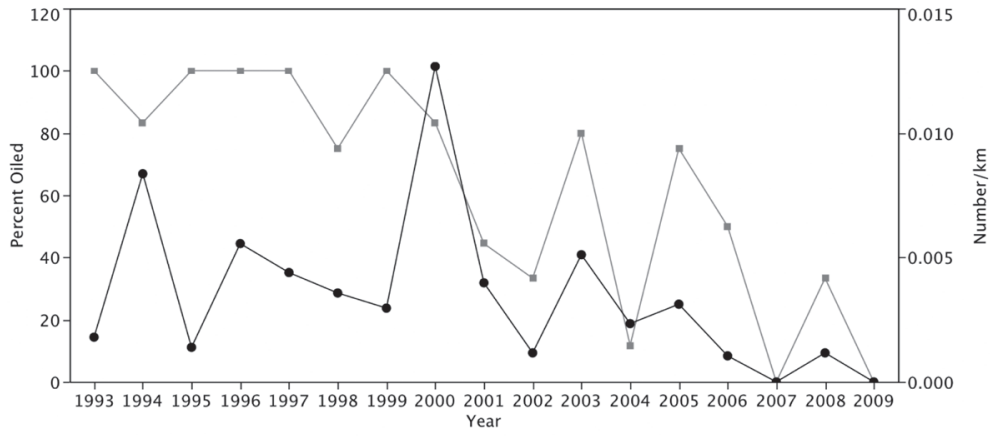

Fig 5g Razorbill ( $\mathrm{n}=88)$.

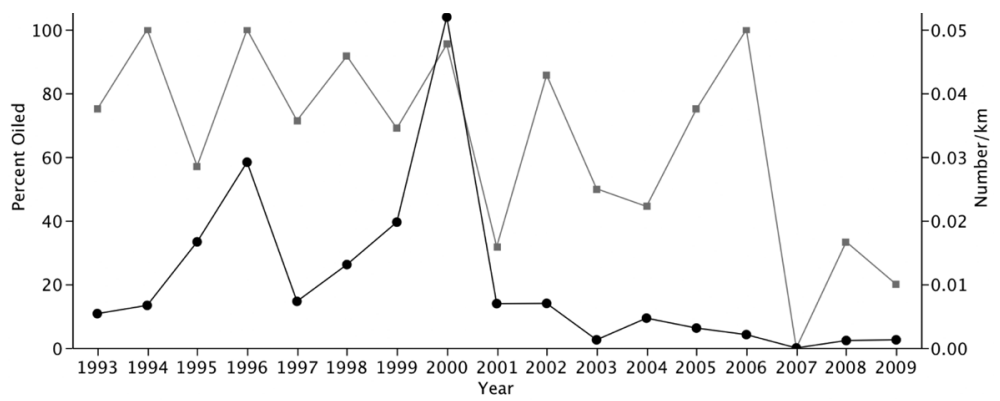

Fig 5 h Large unidentified alcids $(n=202)$.

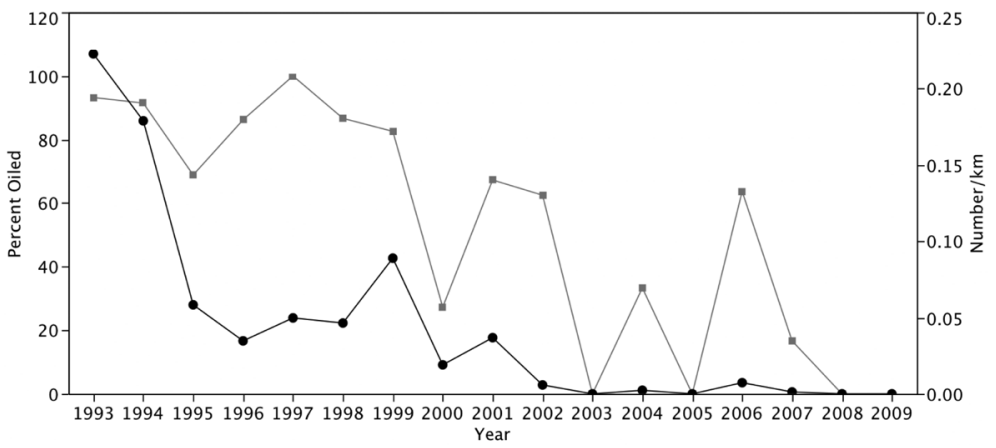

Fig 5i Dovekie $(n=756)$. 


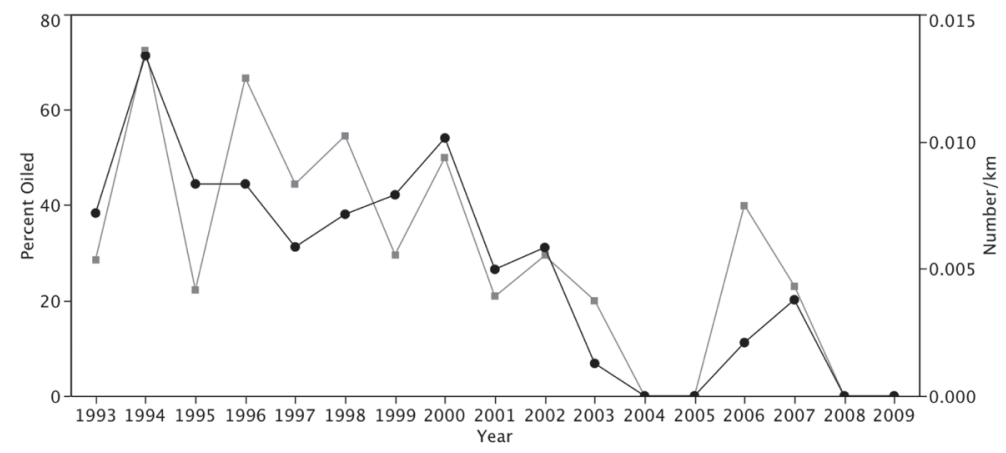

Fig 5j Atlantic Puffin ( $\mathrm{n}=231)$.

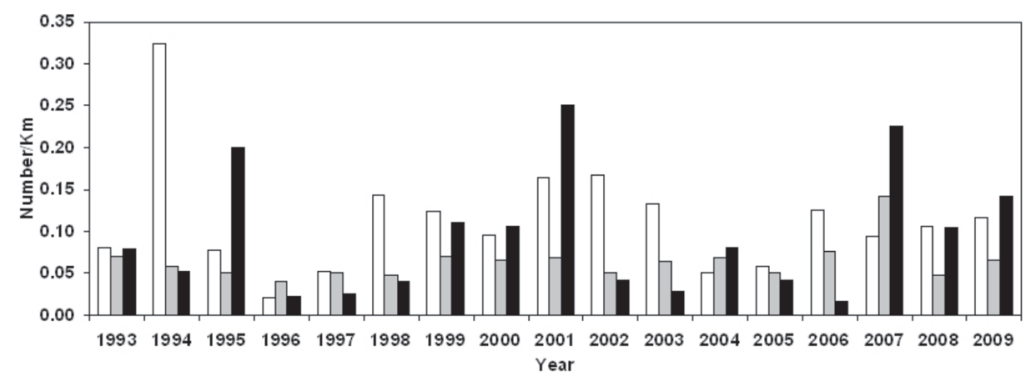

Fig 6 Annual density of complete unoiled corpses (code 0 ) for the three main bird groups. Fulmars and shearwaters ( $\mathrm{n}=1,552$, white); skuas, gulls and terns ( $\mathrm{n}=881$, grey); alcids ( $\mathrm{n}=1,291$, black).

\section{Additional Observations-Beaching of Shearwaters in July 1994}

One week after completion of the June 1994 beached bird survey, a large number of shearwaters came ashore along the south side of the island. Most were recently dead, or dying, while others appeared to have been dead and floating in the ocean for a longer time. A betweensurveys count found that of 274 intact corpses (261 Greater, 12 Sooty and 1 Cory's), $1.8 \%$ were oiled; four Greater Shearwaters were lightly oiled and the single Cory's Shearwater was heavily oiled. None of the shearwater corpses were removed from the beach, and 64 were marked with coloured wire. Recovery of $40 \%$ of the marked birds during the scheduled survey three weeks later suggested that 400 or more birds may have beached in the interval between surveys. This incidental observation was not used to adjust the 1993-2009 survey data, which are based on corpses found during the actual survey periods. 
Table 3 Summary of observations from three beached-bird events at Sable Island.

\begin{tabular}{lccc}
\hline & Jan 21-Feb 02 & Feb 27-Mar 06 & Dec 22-30 \\
& $\mathbf{1 9 7 5}$ & $\mathbf{1 9 8 4}^{\mathbf{1}}$ & $\mathbf{1 9 8 6}$ \\
\hline South beach survey (km) & & 28 & 30 \\
North beach survey (km) & 3 & 28 & 28 \\
Survey duration (days) & 10 & 8 & 9 \\
Total corpses & 482 & $757^{2}$ & 2,607 \\
Distribution & $95 \%$ on north & $99 \%$ on north & $96 \%$ on north \\
Corpses/km (north) & 161 & 26.9 & 83.6 \\
Oiling rate & $100 \%$ & $<6 \%$ & $100 \%$ \\
\hline Bird groups/species & \% of corpses & \% of corpses & $\%$ of corpses \\
Northern Fulmar & 0.0 & 0.3 & 0.4 \\
Gulls & 0.0 & 0.4 & 0.1 \\
Alcids & 100.0 & 99.3 & 99.5 \\
$\quad$ Large alcids & 22.2 & 3.7 & 3.0 \\
Dovekie & 75.5 & 95.6 & 94.5 \\
Atlantic Puffin & 2.3 & 0.0 & 2.0 \\
\hline
\end{tabular}

${ }^{1}$ Beach survey conducted during Uniacke G-72 gas blowout reported in Shell Canada Resources (1984).

${ }^{2}$ Few specimens were fresh or intact, and most may have beached during January.

${ }^{3}$ Proportion of all corpses found (i.e., complete and fragments).

\section{Additional Observations-Previous Beached Bird Surveys, 1970s and 1980s}

A number of comparable surveys of beached birds were conducted by the first author prior to the 1993-2009 monitoring program. These earlier surveys included investigations of three oiling events (origin of oil not identified) in January 1975, February 1984, and December 1986 (Table 3), and a series of nine additional surveys carried out between February 1985 and December 1986 (Table 4).

On January 21 1975, a large number of oiled bird corpses washed ashore on the eastern quarter of the north side of the island. It was only possible to survey a short section of beach, but between January 21 and February 2, 482 corpses were collected, all of them alcids and all oiled (Table 3). The density of oiled birds on this section of beach was $161 / \mathrm{km}$. The corpses were not evenly distributed along the north side of the island, and there were very few on the south side. Therefore, the corpses found in this limited survey cannot be used to accurately estimate the total number beached on the island during this event, although it is likely that $>1,000$ oiled birds had washed ashore.

On February 22 1984, a gas blowout occurred at the Shell Uniacke $G-72$ well located $20 \mathrm{~km}$ north of the eastern tip of Sable Island (Shell 


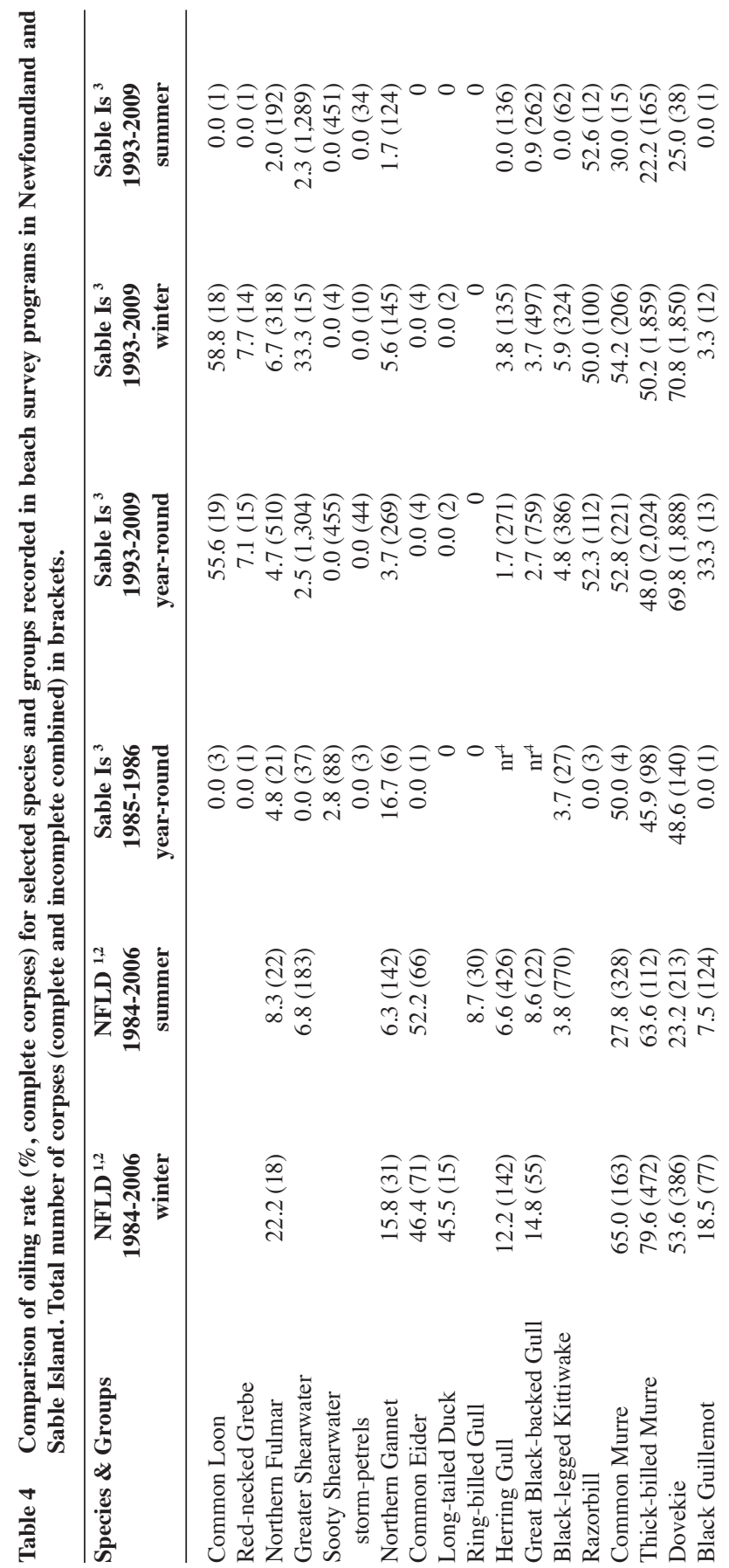




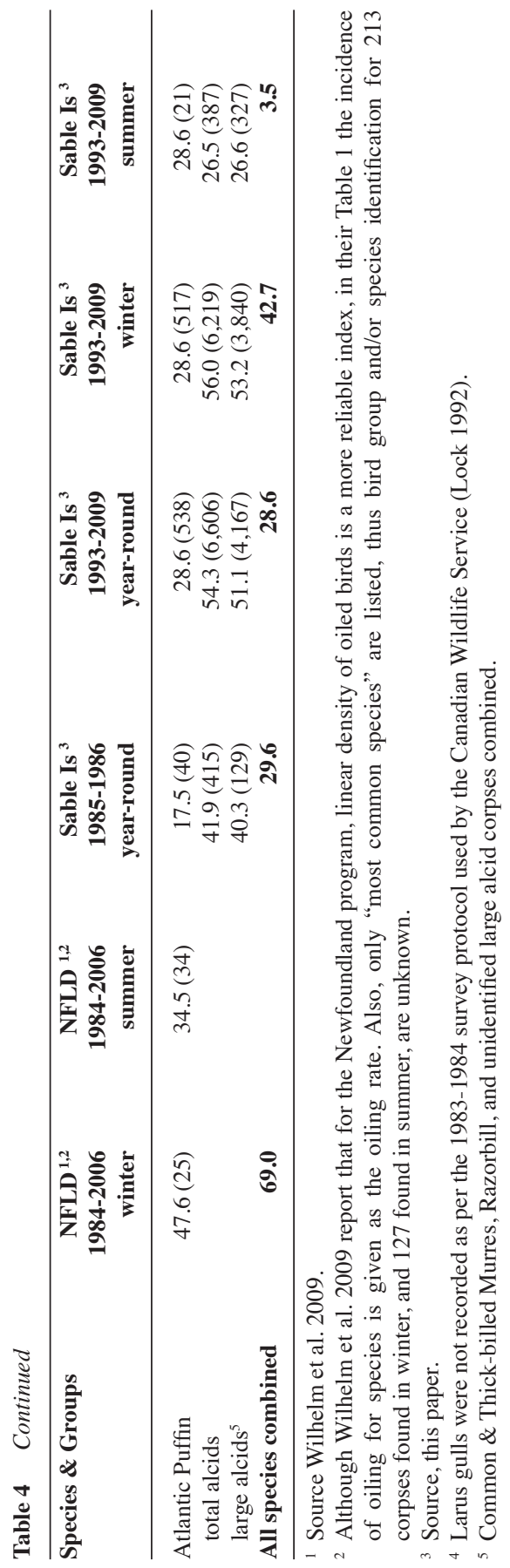


Canada Resources Limited 1984). Monitoring of the north and south beaches began on February 27, with daily surveys until March 6. A total of 757 beached corpses was collected (Table 3), with visible oil residue occurring on $<6 \%$ of them. Species oiled were Northern Fulmar, large alcids, and Dovekie. Few corpses were complete, and many were not fresh and had been on the beach or in the water for some time. An unknown proportion of the birds collected was probably beached in January, prior to the blowout, because on January 22 about 300 unoiled Dovekie corpses had been counted on a $12 \mathrm{~km}$ section of the north beach. Although oiled birds collected offshore after the February incident were found to be oiled with condensate from the blowout, gas chromatographic analyses of residues collected from bird corpses found on the beach during this eight-day period indicated that they were composed of Bunker-C rather than gas condensate (Shell Canada Resources Limited 1984).

Nine beached bird surveys were conducted in 1985-1986 (Table 4). A total of 415 alcid corpses was recovered, of which $42 \%$ were oiled, accounting for $98 \%$ of all oiled birds. Sooty Shearwaters comprised $70 \%$ of the shearwater corpses, of which two (both Sooty) were oiled.

On December 21 1986, only three days after the completion of the above series of surveys, a large number of heavily oiled corpses washed ashore. The shoreline was surveyed again, and between December 22 and 30, a total of 2,607 oiled corpses was recovered from the north and south sides of the island (Table 3). Most occurred on the north side, and those on the south washed ashore about five days after corpses had beached on the north side. About $98 \%$ of the oiled corpses were enveloped in heavy oil, and the rest had patches and smears of oil on wings and underparts.

\section{DISCUSSION}

The results of 171 beached bird surveys conducted between 1993 and 2009 on Sable Island, combined with limited observations from as early as 1975, indicate a markedly declining trend in the incidence of oiling. This decrease in both the oiling rate and the linear density of oiled corpses is consistent with both the lack of beached pelagic tar events observed after 2003 (Lucas \& MacGregor 2006), and the absence of corpses entirely coated in oil after 2001. 


\section{Seasonal Distribution}

Of the 38 pelagic and coastal seabird species commonly found offshore in Atlantic Canada (Brown et al. 1975, McLaren 1981, Lock et al. 1994), 27 were recorded in the 1993-2009 surveys on Sable Island. Of the 52 species of seabird and waterfowl recovered (Table 1), 15 are frequently seen flying or feeding near Sable Island, including those nesting on the island, while 12 are only occasionally sighted (1 to 5 individuals per year) and others are rare vagrants (McLaren 1981).

There were species-specific variations in the numbers of beached corpses. The differences reflected local abundances associated with the phenology of reproduction, feeding, migration, and wintering. During the summer and winter there is a large influx of non-breeding birds into the north Atlantic Ocean, including in the study region, with the greatest densities occurring near the edge of the continental shelf and on shallow banks (Brown et al. 1975, Lock et al. 1994). Post-breeding Dovekie, Thick-billed Murre, Black-legged Kittiwake, and Northern Fulmar are particularly abundant in the region during September through March. During the summer millions of other birds migrate north from the Southern Hemisphere to spend their non-breeding season in the northwest Atlantic. Greater and Sooty Shearwaters are on the Scotian Shelf in May through September (Chardine 1995), and flocks of as many as 5,000 birds have been observed sitting on the water near Sable Island (McLaren 1981). Corpses of Northern Fulmar were most abundant in March through May, somewhat earlier than might be expected based on their seasonal peak abundance reported by Lock et al. (1994), and with a lesser high in October-November. Corpses of Northern Gannet occurred most frequently in October through December, during the period when this species disperses southward from its breeding colonies north of the study area, to overwintering habitat between New England and the Gulf of Mexico (Mowbray 2002). Bird corpse numbers peaked in winter, and alcids comprised the majority recovered, reflecting the predominance of arctic-breeding birds, such as Thick-billed Murre and Dovekie, which overwinter in the region (Brown 1985, Lock et al. 1994).

Bird corpses afloat in the open ocean are strongly influenced by wind speed and direction, with reported rates of drift ranging from $2.2 \%$ to $4.6 \%$ of the wind speed (Hope Jones et al. 1970, Bibby \& Lloyd 1977, Bibby 1981, Flint \& Fowler 1998). In the Sable Island Bank region there is a prevalence of winds from westerly quadrants at all seasons, in winter particularly from the northwest, and in sum- 
mer and early autumn more so from the southwest. In late autumn and spring the westerlies are more variable. Moreover, the frequent passage of cyclonic systems through the region can result in strong winds, usually of short duration (a few days), from easterly quadrants (Environment Canada 1984). Prevailing winds, as well as seasonal abundance, largely account for differences between bird species and groups in corpse density on the north and south sides of the island. For example, the greater number of shearwater corpses found in summer reflects both their seasonal distribution and the predominance in summer of southerly and southwesterly winds that would move their corpses towards the island from areas of their greatest abundance to the west and south (Lock et al. 1994).

\section{Oiled Seabirds and Waterfowl}

It has been reported that bird corpses at sea lose buoyancy and sink after about eight days (Wiese 2003), and because they would not wash ashore, they account for an unknown proportion of birds oiled at sea that are not recovered in beach surveys. However, on Sable Island, scavenged corpses (Code 4) floating just below the surface or moving along the sea bottom are commonly seen within the surf zone and washing ashore (ZL unpublished observations). This may account for the higher proportion of incomplete corpses (48\%) found on Sable Island compared with the $30 \%$ reported from surveys in southeastern Newfoundland (Wilhelm et al. 2009).

The relatively larger number of incomplete corpses found on Sable Island likely explains some survey results for which the oiling rate based on all corpses is higher than that based only on complete corpses (Table 2). The oiling rate expressed as a proportion of total corpses (complete and incomplete combined, Codes 0 - 4) is generally within four percentage points of the oiling rate as a proportion of complete corpses (Codes 0 - 3), and in some cases slightly exceeds the coded oiling rate. For example, the overall oiling rate for 1993-2009 based on complete corpses of the most abundant species (Table 2) is $28.9 \%$, while for the same group of species the rate is $32.7 \%$ if based only on incomplete corpses (Code 4). The oiling rate for complete Common Murre corpses is 5.3 percentage points lower than that for incomplete corpses (Table 2). However, in the small alcids (Atlantic Puffin and Dovekie), the coded oiling rate markedly exceeds the rate for complete and incomplete corpses combined by 7.6 and 18.7 percentage points, respectively. Overall, these results suggest that for many species the 
indices of oiling based on total corpses are roughly comparable to those based on complete corpses.

On Sable Island the seasonal and annual variations in numbers of oiled birds were largely a reflection of the proportions of oiled alcids. Seabird species differ in their vulnerability to oil pollution, with the most susceptible being those that spend much of their time on the water roosting, swimming, and diving. Such birds, considered to be "primarily aquatic", include loons, grebes, cormorants, ducks, and alcids (Chardine 1995, Camphuysen \& Huebeck 2001). The generally less vulnerable "aerial" species, which spend more time flying, include fulmar, shearwaters, storm-petrels, gannet, jaegers, skuas, gulls, and terns. Some of the latter are less susceptible than others. For example, Great Black-backed and Herring Gulls are surface-feeding seabirds that commonly roost on land; Northern Fulmars are also surface-feeding birds, but they generally roost on the water. This may account for the somewhat higher oiling rate for fulmars compared with Larus gulls at Sable Island, $4.7 \%$ and 2.5\%, respectively. Similarly, Wilhelm et al. (2009) report winter oiling rates for fulmars that are higher than those for Larus gulls.

Seasonal variations in the occurrence of beached oiled corpses also reflected prevailing winds. If wind is the primary force directing the movements of floating bird corpses, it is likely that many oiled corpses found on Sable Island in winter represent birds that had encountered the pollution northwest through northeast of the island. Most of those found in summer may be birds affected in areas to the southwest through southeast of the island. However, some corpses are likely transported past Sable Island and then drift back towards the island when a change in wind direction occurs.

The higher proportion of oiled alcid corpses on the north beach in winter is consistent with the predominance of these birds in the region in winter, the prevalence of strong northerly winds, and the location of areas of heavy marine traffic to the north and northwest of the island. Fewer alcids are in these offshore waters during the summer, and this is reflected in the much lower proportion of oiled birds recorded on Sable Island during that season.

Shearwaters spend less time on the sea surface than alcids do, and are thus less exposed to oil pollution. Nevertheless, the relatively low oiling rate observed for shearwaters suggests that they do not often encounter oil in waters around Sable Island during the summer. 
The small number $(<0.5 \%$ of total birds recorded $)$ of live oiled birds seen on Sable Island (Lucas \& MacGregor 2006) contrasts with findings in some Newfoundland surveys, where 50-65\% of oiled birds were found alive (Chardine \& Pelly 1994). These authors suggested that because oil kills birds quickly in cold waters as a result of hypothermia, many of the birds found in coastal Newfoundland likely encountered the pollution relatively close to shore. Thus the low numbers of live oiled birds found at Sable Island may indicate that birds do not encounter the pollution close to the island.

Five species of seabird (two gulls, two terns, and one storm-petrel) and four of waterfowl regularly breed on Sable Island, albeit in relatively small numbers compared with the millions of non-breeding individuals that summer and winter in Scotian Shelf waters. However, the species that nest on the island, as well as those that overwinter there (e.g., Great Black-backed and Iceland Gulls, and Red-breasted Merganser), forage in or otherwise spend some time on waters surrounding Sable Island, and so would be exposed to any oil pollution in the vicinity. Nevertheless, there is a relatively low rate of oiling in these species.

\section{Comparison with Earlier Surveys on Sable Island}

The intervals between the nine surveys conducted in 1985-1986 ranged from 37 to 122 days, and the program covered less than two years, and so the observations are not fully comparable with those of the 1993-2009 program. The earlier results do, however, indicate similar trends in species composition and seasonal distribution of beached birds, and some useful comparisons can be made (Table 4). All 16 species found during 1985-1986 also occurred in 1993-2009. The proportions of the most frequently observed species were similar, although shearwaters were an exception. In 1985-1986, 70\% of the shearwaters recovered were Sooty Shearwaters, but in 1993-2009 the proportions were reversed, with $74 \%$ being Greater and these outnumbered Sooty Shearwaters in all years during the latter program. The seasonal distributions of species in the surveys of 1985-1986 and 1993-2009 were broadly similar: most alcid corpses were found in winter and early spring, and most shearwaters in mid-summer.

The average oiling rate for all species combined was $29 \%$ in both the 1985-1986 and the 1993-2009 survey programs, and is higher than the $11 \%$ found in a program of 14 beach surveys carried out by Environment Canada on Sable Island between May 1983 and July 
1984 (Lock 1992). However, Dovekie corpses, most of which (92\%) occurred in a January 1983 "wreck" of that species, predominated in the Environment Canada surveys, comprising $74 \%$ of all birds found, of which only $3 \%$ were oiled. When Lock (1992) excluded the Dovekie corpses, the overall oiling rate for the 1983-1984 surveys was 34\%. Also, Lock (1992) noted that an overall high proportion of oiled Northern Fulmars and shearwaters was the result of a single oiling incident in May-June 1984. The surveys of 1983-1984 (Lock 1992) and 1985-1986 were both of short duration, each undertaken for less than two years. The results of relatively short-term programs are more likely to be skewed by large events.

Although some of the annual and species-specific oiling rates from the first decade of our 1993-2009 monitoring program are higher than those found in earlier surveys on Sable Island, there were no large oiling events on the island during the 17 years of our study, comparable to those of January 1975 and late December 1986.

\section{Comparison with Survey Results from Other Areas of Atlantic Canada}

Campbell and Bredin (2007) reported on beach surveys conducted in Cape Breton, Nova Scotia, between 2001 and 2005. They found an overall oiling rate of $37.7 \%$, with murres being the most frequently oiled. However, although Cape Breton is within $200 \mathrm{~km}$ of Sable Island, the total number of seabird and waterfowl corpses recovered (129) was very low compared with that of Sable Island, and of the 14 species recorded, only four were represented by $>10$ specimens (complete and incomplete corpses combined). Campbell and Bredin (2007) suggested that the predominance of offshore winds in winter explained the relatively small numbers of bird corpses observed in Cape Breton.

Although the decline in the level of seabird oiling observed at Sable Island during the latter half of the 1993-2009 is generally consistent with declines reported from Newfoundland (Wilhelm et al. 2009), the overall incidence of oiling was lower than that reported for southeastern Newfoundland (Wiese \& Ryan 1999, Wilhelm et al.2009). Also, there were differences in the seasonality of occurrence and species-specific oiling rates (Table 4) and in the proportions of species found, with Black Guillemot, Common Eider, and Black-legged Kittiwake being more frequently recorded in Newfoundland (Wilhelm et al. 2009). A 
much higher proportion of corpses, particularly those of alcids, was recovered at Sable Island during the winter (Table 5).

\section{Oiling Rate and Linear Density of Oiled Corpses as Indices of Long Term Trends}

The oiling rate is an international standard for presenting data from beached bird surveys (Camphuysen 1998). However, it is recognized that changes in non-oil related causes of bird mortality, such as extremely low temperatures, avian diseases, or starvation, can influence oiling rates by changing the 'background level' of clean corpses found in beached bird surveys.

Wilhelm et al. (2009) suggested that the oiling rate may not be a reliable index of long-term trends for vulnerable species in southeastern Newfoundland. They re-evaluated the use of the oiling rate because of a discrepancy in seasonal trends, and concluded that it was unreliable for assessing oil pollution in that region because they had observed a decline in mortality from other causes, such as birds drowning in fishing nets or killed or injured during the annual murre hunt (Wiese \& Ryan 2003) which would have resulted in fewer unoiled birds found in the beach surveys. Consequently, they considered the linear density of oiled birds, rather than the conventional oiling rate, to be a more representative measure for quantifying trends in oil pollution in the Newfoundland region.

During 1993-2009, there was not a similar decline of unoiled murre corpses on Sable Island. Moreover, the Sable Island region is unlikely to be affected by changes in mortality factors associated with the murre hunt or coastal gillnetting, as occur in Newfoundland and Labrador. However, a change in natural mortality was detected on Sable Island in 2007, when the linear density of unoiled corpses of Great Black-backed Gull was more than double the long-term average (Fig 3b). This coincided with an outbreak of avian cholera in open-ocean seabirds in Atlantic Canada (McBurney et al. 2007). In this case, the increased natural mortality was not reflected in a 'decreased oiling rate' because no oiled gull corpses were recovered between 2006 and 2008.

Thus, even though the methods show similar trends, results from the Sable Island program generally indicate that beach survey data provide a better understanding of trends when the oiling rate is presented in the context of the linear density of bird corpses. 
Table 5 Comparison of proportions $(\%)$ of total corpses found in winter and summer in Newfoundland and Sable Island beach survey programs. Number of corpses in brackets.

\begin{tabular}{lcccr}
\hline $\begin{array}{l}\text { Beached Bird } \\
\text { Corpses }\end{array}$ & $\begin{array}{c}\text { NFLD }^{1} \\
\mathbf{1 9 8 4 - 2 0 0 6} \\
\text { winter }\end{array}$ & $\begin{array}{c}\text { NFLD }^{1} \\
\mathbf{1 9 8 4 - 2 0 0 6}^{\text {summer }}\end{array}$ & $\begin{array}{c}\text { Sable Is } \\
\mathbf{1 9 9 3 - 2 0 0 9} \\
\text { winter }\end{array}$ & $\begin{array}{r}\text { Sable Is } \\
\mathbf{1 9 9 3 - 2 0 0 9} \\
\text { summer }\end{array}$ \\
\hline $\begin{array}{l}\text { Total Corpses } \\
\quad \text { Codes 0 - 4) }\end{array}$ & $45.7(2,566)$ & $54.3(3,049)$ & $72.2(7,838)$ & $27.8(3,024)$ \\
$\begin{array}{l}\text { Complete Corpses } \\
\quad(\text { Codes 0 - 3) }\end{array}$ & $52.2(1,796)$ & $47.8(1,646)$ & $64.0(3,617)$ & $36.0(2,033)$ \\
$\begin{array}{l}\text { Aerial birds } \\
\text { Alcids }\end{array}$ & $13.0(246)$ & $87.0(1,640)$ & $37.0(1,538)$ & $63.0(2,622)$ \\
\hline
\end{tabular}

${ }^{1}$ Source: Wilhelm et al. 2009.

${ }^{2}$ Fulmar, shearwaters, gannet, and Larus gulls, and includes storm-petrels at Sable Island.

\section{Oil Contamination}

Generic identification of oil residue specimens collected between 1996 and 2005 (Lucas \& MacGregor 2006) indicated that they likely represented 74 marine oil discharge events, of which $77 \%$ were crude oils, $15 \%$ were bunker-fuel oils, and $8 \%$ were bilge-oil mixtures (Lucas $\&$ MacGregor 2006). An additional 42 samples were collected during 2006 to 2009, and the proportion of presumed discharge events involving crude oil was lower (59\%) (Lucas \& MacGregor, unpublished data).

The results of laboratory analyses suggest that in some cases, oiled birds found during a particular survey appeared to have encountered pollution from several different discharge events (Lucas \& MacGregor 2006). This is consistent with the findings of other studies. For example, based on analytical data, Levy (1980) concluded that seabirds collected from the Nova Scotia mainland coast in 1976 were not victims of the then-recent Argo Merchant spill (Powers \& Rumage 1978), but of a variety of other spills (e.g., weathered and unweathered fuel oil, and discharges of various oils that routinely occurred as a consequence of marine shipping and oil industries). Furness and Camphuysen (1997) suggested that chronic oil pollution is a constant process in which variable numbers of seabirds are exposed under variable conditions. Camphuysen (2010) states that the source of chronic pollution within the North Sea area has been comprised of ships' fuel oils rather than crudes, deliberately discharged with bilge waters. 


\section{Possible Reasons for a Decline in Incidence of Oiling Observed at Sable Island}

The results of 50 years of beached bird surveys in the Netherlands showed significant declines in the oiling rates for most species and groups, indicating a reduction of chronic oil pollution in the southern North Sea (Camphuysen 1998, Camphuysen \& Huebeck 2001, Camphuysen 2010). For example the oiling rate for Northern Fulmar declined from $71 \%$ in the 1960 s to $21 \%$ in the 2000 s, and for Razorbill, down from $99 \%$ in the 1960 s to $64 \%$ in the 2000s (Camphuysen 2010). The decline in the linear density of oiled birds in southeastern Newfoundland reported by Wilhelm et al. (2009), and the decrease in the incidence of oiled birds at Sable Island (expressed as both oiling rate and linear density), suggest that there has been a similar reduction of oil pollution in the Northwest Atlantic.

These declines are likely due to a combination of initiatives, such as increased and more effective surveillance to detect illegal dumping of oily wastes, the routine use of onshore oil reception facilities, the ongoing retirement of single-hulled tankers, an increasing proportion of vessels with segregated ballast, the strengthening of laws providing for investigation and charging of suspected polluters, and education of ships' officers and crews about the consequences of illegal dumping. Increased public awareness about the environmental impacts of the exploration, production, and shipping of fossil fuels has supported the implementation and enforcement of legislation by governments of marine states worldwide (Camphuysen 2010).

In Canada, the Integrated Satellite Tracking of Oil Polluters (ISTOP) system became an enforcement tool in 2003, and Bill C-15, passed in May 2005, amended the Migratory Birds Convention Act of 1994, and the Canadian Environmental Protection Act of 1999. These amendments clearly establish that the Acts are enforceable within the $200 \mathrm{~nm}(320 \mathrm{~km})$ limit of the exclusive economic zone of Canada, and they increase the accountability of ships' officers for oil discharges and enable authorities to impose heavier penalties. The timing of these changes in awareness, procedure, and enforcement is consistent with the recent declines in seabird and waterfowl oiling observed in southeastern Newfoundland and Sable Island. 


\section{SUMMARY}

1. Although there were marked fluctuations in annual densities of bird corpses, as has also been reported from Newfoundland (Wiese \& Ryan 2003) and the North Sea (Camphuysen 2010), beached bird surveys on Sable Island between 1993 and 2009, combined with observations from earlier surveys, indicate a declining trend in the incidence of oiling.

2. The decrease in the incidence of oiled bird corpses at Sable Island was evident in both the annual oiling rate and the linear density of oiled corpses.

3. This decline is consistent with a lack of beached pelagic tar events on Sable Island after 2003, and the marked reduction in the proportion of heavily oiled and entirely coated bird corpses, and likely indicates a diminishing intensity of oil pollution in the region's waters.

4. Results from the Sable Island program indicate that beach survey data provide a better understanding of trends when the oiling rate is presented in the context of the linear density of bird corpses.

5. For most species found as corpses at Sable Island, the oiling rate expressed as a proportion of total corpses (complete and incomplete combined) is roughly comparable with the oiling rate as a proportion of complete corpses only (i.e., coded oiling rate).

6. Generic identification of oil samples collected between 2006 and 2009 indicated that, as reported for 1996 to 2005 (Lucas \& MacGregor 2006), most oil residues represented three categories of presumed discharge events: crude oils, fuel oils, and bilge oils. However, in 2006-2009, the proportion of discharge events involving crude oil was 59\% compared with $77 \%$ in the earlier period.

7. While Sable Island serves as an excellent platform to monitor trends in the numbers and oiling rates of seabirds in the wider Scotian Shelf region, its seasonally resident seabirds and waterfowl provide an especially good indication of oil pollution in adjacent waters. The relatively low rate of oiling found in seabird species that commonly forage near Sable Island, and the small proportion of live oiled birds, suggest that the intensity of local oil pollution is not greater than occurs more generally in the Scotian Shelf region. This is in spite of the fact that offshore exploration and 
production activities for natural gas have occurred close to Sable Island since the 1970s.

8. The long-term beach survey program on Sable Island provides useful information on trends in rates and generic sources of oil pollution, and in the species composition and seasonal distribution of affected birds. The data presented here provide a baseline against which future surveys can be compared. During the winter, Sable Island is generally downwind of areas where seabirds likely encounter most oil pollution, so the island is a useful platform for monitoring bird mortality in the region. Moreover, because Sable Island is roughly centered in an area of offshore oil and gas production, with generally increasing ship traffic, the island is important for continued monitoring of environmental impacts associated with these industrial activities.

Acknowledgements This study was funded by ExxonMobil Canada/Sable Offshore Energy and Encana Corporation as part of their Environmental Effects Monitoring Program. G. Forbes, Manager, and staff of the Sable Island Station (Meteorological Service of Canada), the Nova Department of Energy, and the Nova Scotia Museum of Natural History provided valuable assistance.

\section{LITERATURE CITED}

Bibby, C.J. (1981) An experiment on the recovery of dead birds from the North Sea. Ornis Scandinavica 12: 261-265.

Bibby, C.J., \& Lloyd, C.S. (1977) Experiments to determine the fate of dead birds at sea. Biological Conservation 12: 295-309.

Brown, R.G.B. (1985) The Atlantic alcidae at sea. In The Atlantic Alcidae. The Evolution, Distribution and Biology of the Auks Inhabiting the Atlantic Ocean and Adjacent Water Areas (Nettleship, D.N., \& Birkhead, T.R. eds). Academic Press, pp. 384-425.

Brown, R.G.B., Gillespie, D.I., Lock, A.R., Pearce, P.A., \& Watson, G.H. (1973) Bird mortality from oil slicks off Eastern Canada, February-April 1970. Canadian Field-Naturalist 87: 225-234.

Brown, R.G.B., Nettleship, D.N., Germain, P., Tull, C.E., \& Davis, T. (1975) Atlas of Eastern Canadian Seabirds. Canadian Wildlife Service, Environment Canada, Ottawa.

Campbell, G., \& Bredin, K. (2007) Cape Breton beached bird survey five-year report 2001-2006. Bird Studies Canada - Atlantic Region, Environment Canada, Sackville, New Brunswick. 
Camphuysen, C.J. (1998) Beached bird surveys indicate decline in chronic oil pollution in the North Sea. Marine Pollution Bulletin 36: 519-526.

Camphuysen, C.J. (2010) Declines in oil rates of stranded birds in the North Sea highlight spatial patterns in reductions of chronic oil pollution. Marine Pollution Bulletin 60: 1299-1306.

Camphuysen,C.J.,\& Huebeck, M.(2001) Marine oil pollution and beached bird surveys: The development of a sensitive monitoring instrument. Environmental Pollution 112: 443-461.

Chardine,J.W.(1991) Newfoundland: Crossroads for seabirds and shipping in the NW Atlantic. In The Effects of Oil on Wildlife (White, J., Frink, L., Williams, T.M., \& Davis, R.W.eds). International Wildlife Rehabilitation Council publication, Suisun, CA., pp. 113-120.

Chardine, J.W. (1995) The distribution and abundance of aquatic birds in Canada in relation to the threat of oil pollution. In Wildlife and Oil Spills: Response, Research, and Contingency Planning (Frink, L. ed). Tri-State Bird Rescue \& Research Inc., pp. 23-36.

Chardine, J.W., \& Pelly, G. (1994) Operation Clean Feather: reducing oil pollution in Newfoundland waters. Technical Report Series No. 198, Canadian Wildlife Service, Atlantic Region.

Cook, A., Losier, R., \& Davis, K. (2006) Regional oil spill overview. In The Effects of Oil on Wildlife: Proceedings of the Eighth International Conference, August 3-5, 2005, St. John's, Newfoundland, pp. 45-54.

Environment Canada (1984) Principal station data, Sable Island. PSD92, Atmospheric Environment Service, Canadian Climate Program, Canadian Government Publishing Centre, Supply and Services Canada, Ottawa K1A 0S9.

Flint,P.L., \& Fowler, A.C.(1998) A drift experiment to assess the influence of wind on recovery of oiled seabirds on St Paul Island, Alaska. Marine Pollution Bulletin 36: 165-166.

Furness, R.W., \& Camphuysen, C.J. (1997) Seabirds as monitors of the marine environment. ICES Journal of Marine Science 54: 726-737.

Hannah, C.G., Loder, J.W., \& Wright, D.G. (1996) Seasonal variation of the baroclinic circulation in the Scotia-Maine region. In Bouyancy Effects on Coastal and Estuarine Dynamics, Coastal and Estuarine Studies, vol 53 (Aubrey, D.G., \& Friedrichs, C.T. eds). American Geophysical Union, Washington, DC, pp. 7-29.

Hannah, C.G., Shore, J.A., Loder, J.W., \& Naimie, C.E. (2001) Seasonal circulation on the Western and Central Scotian Shelf. Journal of Physical Oceanography 31: 591-615.

Hope Jones, P., Howells, G., Reese, E.I., \& Wilson, J. (1970) Effect of Hamilton Trader oil on birds in the Irish Sea in May 1969. British Birds 63: 97-110.

Levy, E. (1980) Oil pollution and seabirds: Atlantic Canada 1976-77 and some implications for northern environments. Marine Pollution Bulletin 11: $51-56$.

Lock, A.R. (1992) Sable Island: an offshore site for sampling marine bird mortality in the Northwestern Atlantic Ocean. In Managing the Envi- 
ronmental Impact of Offshore Oil Production (Ryan, P. ed). Proceedings of the 32nd Annual Meeting of the Canadian Society of Environmental Biologists, St. John's NF, pp. 35-49.

Lock, A.R., Brown, R.G.B., \& Gerriets, S.H. (1994) Gazetteer of marine birds in Atlantic Canada. Canadian Wildlife Service, Environmental Conservation Branch, Environment Canada, Atlantic Region, Dartmouth, Nova Scotia.

Lucas, Z. (1989) Monitoring persistent litter in the marine environment on Sable Island, Nova Scotia. Marine Pollution Bulletin 24: 192-199

Lucas, Z., \& Daoust, P-Y. (2002) Large increase of harp seals (Phoca groenlandica) and hooded seals (Cystophora cristata) on Sable Island, Nova Scotia, since 1995. Polar Biology 25: 562-568.

Lucas, Z., \& Hooker, S.K. (2000) Cetacean strandings on Sable Island, Nova Scotia, 1970 - 1998. Canadian Field-Naturalist 114: 45-61.

Lucas, Z., \& MacGregor, C. (2006) Characterization and source of oil contamination on the beaches and seabird corpses, Sable Island, Nova Scotia, 1996-2005. Marine Pollution Bulletin 52: 778-789.

Lucas, Z., \& Natanson, L.J. (2010) Two shark species involved in predation on seals at Sable Island, Nova Scotia, Canada. Proceedings of the Nova Scotian Institute of Science 45: 64-88.

McBurney, S., Whitney, H., Blehert, D., Dunphy, R., Robertson, G., \& Wilhelm, S. (2007) Avian cholera in open ocean seabirds of Atlantic Canada. Wildlife Health Centre Newsletter 13: 5-6.

McLaren, I.A. (1981) The birds of Sable Island, Nova Scotia. Proceedings of the Nova Scotian Institute of Science 31: 1-84.

Mowbray, T.B. (2002) Northern Gannet (Morus bassanus). In The Birds of North America Online (Poole, A. ed). Ithaca: Cornell Lab of Ornithology; Retrieved from the Birds of North America Online: http://bna.birds. cornell.edu/bna/species/693

Percy, R., \& Dewis, S. (2006) Regional oil spill overview. In The Effects of Oil on Wildlife: Proceedings of the Eighth International Conference, August 3-5, 2005, St. John's, Newfoundland, pp. 103-109.

Powers, K.D., \& Rumage, W.T. (1978) Effect of the Argo Merchant oil spill on bird populations off the New England coast, 15 December 1976 - January 1977. In The Wake of the Argo Merchant, Proceedings of a Symposium held 11-13 January, 1978 at Center for Ocean Management Studies, University of Rhode Island, pp. 142-148.

Shell Canada Resources Limited (1984) Report on the environmental program associated with the blowout at Shell et al. Uniacke G-72. Prepared by Martec Limited, September 1984. Unpublished report.

Sutcliffe, Jr. W.H., Loucks, R.H., \& Drinkwater, K.F. (1976) Coastal circulation and physical oceanography of the Scotian Shelf and the Gulf of Maine. Journal of the Fisheries Research Board of Canada 33: 98-115.

Wiese, F.K. (2003) Sinking rates of dead birds: Improving estimates of seabird mortality due to oiling. Marine Ornithology 31: 65-70. 
Wiese, F.K., \& Ryan, P.C. (1999) Trends of chronic oil pollution in southeast Newfoundland assessed through beached-bird surveys 1984-1997. Bird Trends 7: 36-40.

Wiese, F.K. \& Ryan, P.C. (2003) The extent of chronic marine oil pollution in southeastern Newfoundland waters assessed through beached bird surveys 1984-1999. Marine Pollution Bulletin 46: 1090-1101.

Wilhelm, S.I., Robertson, G.J., Ryan, P.C., Tobin, S.F. \& Elliot, R.D. (2009) Re-evaluating the use of beached bird oiling rates to assess longterm trends in chronic oil pollution. Marine Pollution Bulletin 58: 249-255.

Žydelis, R., Dagys, M. \& Vaitkus, G. (2006) Beached bird surveys in Lithuania reflect marine oil pollution and bird mortality in fishing nets. Marine Ornithology 34: 161-166. 
